Portland State University

PDXScholar

1975

\title{
Assessment of Short Term Behavioral Changes in Emotionally Handicapped Children Enrolled in a Special Education Program
}

\author{
James S. Johnston \\ Portland State University \\ Karen Shilling \\ Portland State University
}

Follow this and additional works at: https://pdxscholar.library.pdx.edu/open_access_etds

Part of the Social Work Commons

Let us know how access to this document benefits you.

\section{Recommended Citation}

Johnston, James S. and Shilling, Karen, "Assessment of Short Term Behavioral Changes in Emotionally Handicapped Children Enrolled in a Special Education Program" (1975). Dissertations and Theses. Paper 1890.

https://doi.org/10.15760/etd.1888

This Thesis is brought to you for free and open access. It has been accepted for inclusion in Dissertations and Theses by an authorized administrator of PDXScholar. Please contact us if we can make this document more accessible: pdxscholar@pdx.edu. 


\author{
ASSESSMENT OF SHORT TERM BEHAVICRAL CHANGES IN \\ EMOTIONALLY HANDICAPPED CHILDREN ENROLLED \\ IN A SPECIAL EDUCATION PROGRAM
}

by

JAMES S. JOHNSTON

KAREN SHILLING

A repont submitted in partial. fulfillment of the requirements for the degree of

MASTER OF

SOCIAL WORK

Portland State University

1975 
TABLE OF CONTENTS

PAGE

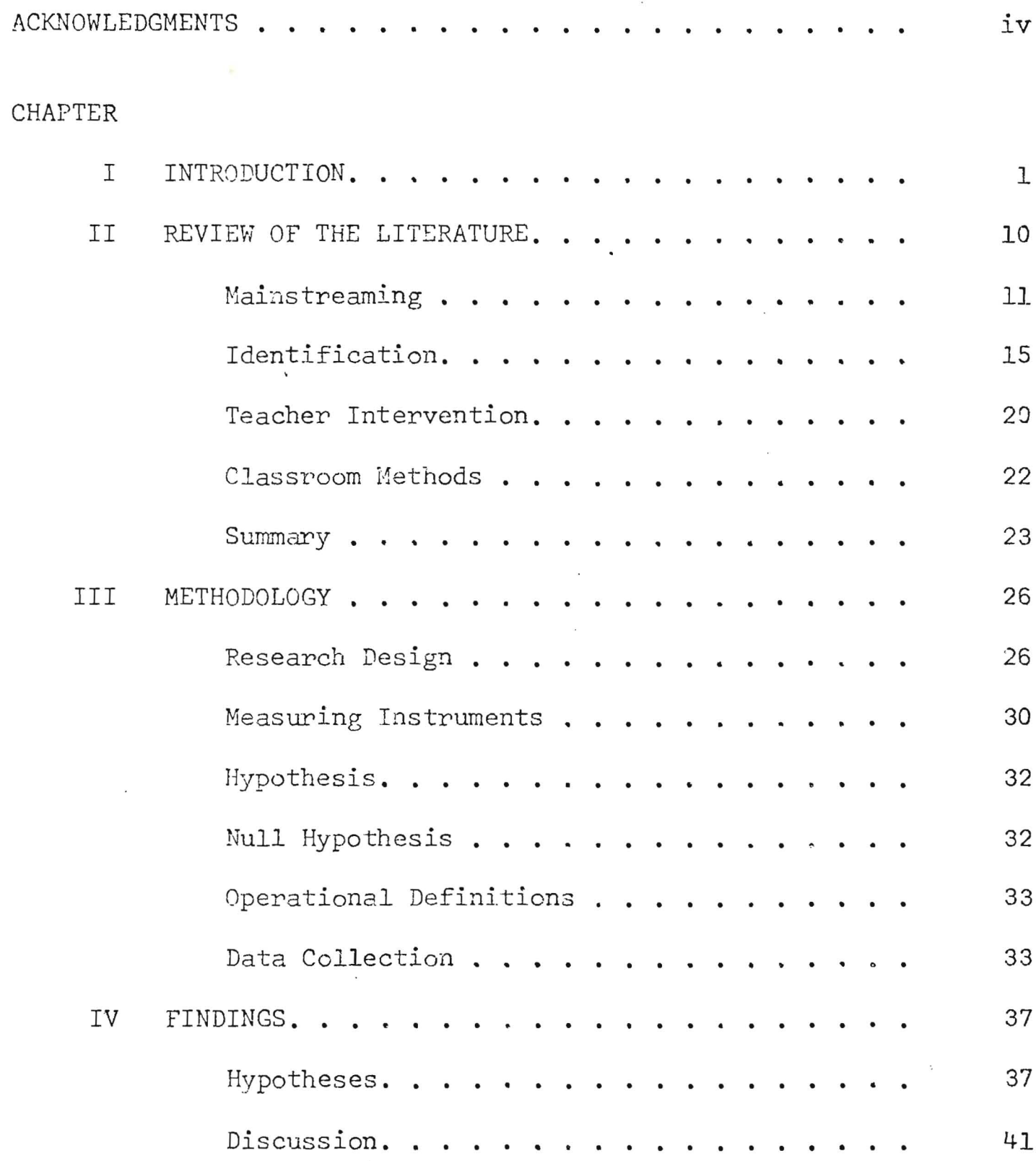


CHAPTER

PAGE

V CONCLUSION. . . . . . . . . . . . .

44

Implications of Study . . . . . . . .

47

Recommendations . . . . . . . . .

BIBLIOGRAPHY, . . . . . . . . . . . . . . . .

APPENDIX. . . . . . . . . . . . . . . . . 


\section{ACKNOWLEDGMENTS}

We would like to thank the following people for their co-operation and interest in our research project: Dean Forbes, Bill Clawson, Carol Chaney, and the ciassroom teachers and aides in the Area II Program for the Emotionally Handicapped. We also thank the teachers and principals of the schools who participated in the comparison group. If it were not for these individuals taking time out from their busy schedules, our project would not have been possible. 


\section{CHAPTER I}

\section{INTRODUCTION}

This study attempts to assess short term behavioral changes, as measured by the Hewett Behavional Checklist; in emotionally handicapped children enrolled in three of the special education classrooms.

The public school systems in this country are endeavoring to respond to the educational needs of a variety of students. For a number of years, the emotionally disturbed ${ }^{l}$ child was excluded from the educational process. School administrators have often felt that treatment of emotional disturbance belonged to the domain of the mental health worker. Little was done for the emotionally disturbed child in the way of public school programs prior to the 1950's. During the post World War II years, it has become increasingly evident that--in dealing with the emotionally disturbed child--education, clinical psychology, social work, and psychiatry have, in common, a child with a history of failure, a child who has developed subtle means for avoiding and covering up a badly damaged self-esteem, a child who is often angry, easily panicked, easily frustrated, and frequently depressed (Brown 1968). Studies since the early 1960's have shown that disruptive behavion common to emotional disturbance is a response to inappropriate academic demands and an appropriate

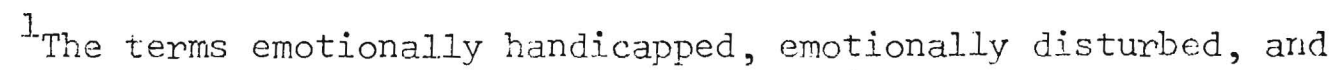
maladjusted are used interchangeably in the literatume. 
area of intervention for these professionals (Allen 1970; Burban, Ford 1971).

Portland public schools annual reports from 1965-1972 indicate that there are increasing numbers of children in the Portland schools manifesting emotional problems which make it difficult if not impossible for them to achieve in a regular classroom setting. Some of these children are depressed, withdrawn and are unable to function in normal classroom activities. Others are hostile, acting out and overly aggressive, and they disrupt the activities of the classroom. These children fail. to progress normally both academically and socially in the normal classroom setting. They also disturb the progress of the normal children and place a burden on the teacher which prevents her from giving the other children in the classroom the time, attention and skills that they require for normal progress.

In an effort to meet the needs of the emotionally handicapped child, the Portland public schools have established a city-wide program that consists of nine classrooms, three in each area. The prupose of the classes, according to the Area II Program for the Emotionally Handicapped, Evaluation Plan 1974-75, is to improve the social and emotional behavion of the children who are admitted to the schools in Area II, Vernon, Lent and scott. ${ }^{2}$

It is the aim of this special education program to provide educational, diagnostic, prescriptive and counseling services, directly and indirectly to emotionally handicapped children. In addition,

${ }^{2}$ See Appendix p. 60-66. 
opportunities for counseling services are provided for the parents of these children. The goal of this program is to help the child gain the skills and controls necessary for him to function adequately in a regular classroom.

For the purposes of placement in the Area II program for the emotionally handicapped child, the definition of Multnomah County Intermediate Education District was used: "inability to learn, unsatisfactory interpersonal relationships, inappropriate behavior, unhappiness, repetitive symptoms of illness after stress." ${ }^{3}$ one facit. of emotional disturbance which confounds educators is that a psychological problem is deep, intangible and complex, showing itself only through behavior and then in many disguises (Redl 1959). In searching for definitive behaviors which might be associated with emotional disturbance, professionals involved in treatment and researchers evaluating those treatment programs are left without precise criteria of normal mental and emotional health. Some adults and some children act almost all the time as though important parts of their behavion were beyond control; Redl (1959) states that these individuals may be considered emotionally disturbed.

Education has responded to the existence of exceptional children with various administrative plans. Chief among these plans are (1) the residential school (2) the special school in a local cormunity (3) the special class (4) the resource room (5) the itinerant teacher on consultant (6) home and hospital teaching. Pesidential schools are

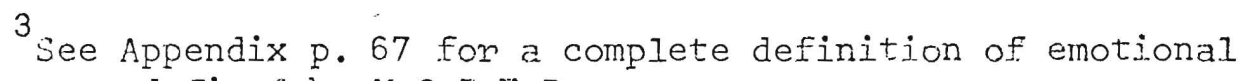
handicap as defined by M.C.I.E.D. 
chronologically the oldest response to the education of exceptional children. A growing dissatisfaction with this type of education on the part of parents of handicapped children and the development of urban centers led to the establishment of community special schools. Lack of contact with normal peers and transportation problems led to the development of special classes located in a regular elementary or secondary school. Inappropriate usage of the special class concept led to the development of the resource room--an attempt to achieve more fully an integrated experience for handicapped children. In the latter program, the child remains on the rolls of a regular class, attending the resource center only for help in areas where he needs specific aid. The only difference between the resource room teacher and the itinerant teacher is that the latter has no special room of her own and seeks out the child in his regular classroom. For those children judged too ill--either physically on emotionally to attend school--a teacher is sent to the home once on twice a week in order to attempt an educational program (Cruickshank, Johnson 1958). According to Schulz (1971), educational programs for emotionally disturbed and socially maladjusted children have been in a few public schools for over. 50 years, usually in langer cities. Only in the past few years have programs developed in smaller school districts. In 1948,90 public school districts operated special education programs for approximately 15,300 children. In 1971, 100,000 children plus 65,000 in institutions were receiving some form of special education. The growth of programs has been late and slow, typically, the last of the total spectrum of special services. In part, this is a 
result of the lack of a clear definition of the problem (Schulz 1971; Monse, Cutler, Fink 1964). Schulz ascertained that 18 states (1/3) estimated the prevalence of emotional disturbance among public school population to be $2 \% ; 7$ states, $3 \%, 6$ states $5 \%$ and 7 states had no estimate. He discovered that twelve services were specified: (1) special class prograin (2) resource room (3) crisis intervention (4) itinerant teacher program (5) academic tutoring (6) homebound instruction (7) guidance counselor (8) school social worker (9) psychotheraoy by school psychologist (10) psychiatric consultation (II) public school transportation to non-school agency (12) payment by public school for a private school. These various programs testify to the public school's adherence to the philosophy of "equal education for alI".

Oregon Revised Statute 339.030 , passed in 1973, gives legal basis to the philosophy and supports the general recognition by the public and school administrators of the

vital importance of the primany social institutions such as the school and the family in preventing and treating emotional problems...primary prevention, early case finding, and treatment in the context of the existing institutionsl agencies have become of central importance. In this development public schools play a key role. The school is a mass agency which cuts across the total population and thus, serves as a gathering place for children upon whom our primary preventive efforts may be focused. Further, the school compels the child's attendance. It has contact with the child over a long period of his life and has a commitment to mental health goals (Morse, Cutler, Fink 1964).

Portland public schools have a Iong history of educational programs designed to meet the special needs of children who are incapable of achieving in a normal classroom. In 1908, the Portiand 
public schools established a class for deaf children at the request of their parents (Walker 1945). In the same year a class was estabIished for mentally retarded children. Both classes were provided with a curriculum to meet these children's needs and teachers taught them skills which would eouip them for a gainful occupation when they left school. These programs have increased in number since their origin and are still active at this time. The original programs for children with these handicaps were held in grade schools, but eventually a pre-vocational school for girls who were slow-learners was established at the Girls' Polytechnical high school (Walker 1945). In 1954, an experimental class for children of high school age who had low intelligence quotients was established in a Portland high school. In 1928, there were 500 children in Portland errolied in classes for retarded children. On the basis of a Stanford Binet Intelligence test, these children had intelligence quotients ranging from 50 to 75 and were considered permanently disabled (Walker 1945). A special class was established in 1908 for children with speech defects. Throughout the years, this program did not expand, although twenty years later, when a survey was made by the Department of Research, Portland public schools, it was discovered that 58 children in the schools had definite speech defects. However, a structured remedial speech program was not established until 1943. In 1931, sight-conservation classes were established in the public schools and expanded in 1937. These classes are still in existence at this time. 
Since the 1920's, the Portiand public schools have provided teaching services to the children in Doernbecher Hospital, Shrine Memorial Hospital, the Open-Air School oniginated by the Oregon Tuberculosis Association, and the Crippled Children's Centers. Classes for the physically handicapped who were residing in their homes were also established by the public schools in 1937. These programs, like those described in the preceding paragraphs, are still in existence today.

In the early part of the century, little was known about the emotional disturbances of children and the effect of such difficulties on academic achievement. It is possible that many of these children were considered of sub-normal intelligence and placed in classes for retarded children. No provision was made for their education in the public school. However, the school district did provide teachers during this period, for the Juvenile Court's Detention Home and the Louise Home. Because some of the children in these facilities had been involved in behaviors characteristic of the acting out child, i.t is quite possible that they suffered from emotional handicaps.

In 1954, the Portland public schools established a mental hygiene clinic to assist in the prevention, diagnosis, and treatment of childhood emotional and social problems which would prevent a child from participating in and receiving instruction from the school experience. In 1957 , as reported in the Archives, Portland public schools, the Portland public schools defined emotionally disturbed youth as..."those children who must have treatment or therapy before they can accomplish academically". In the same year 
small classes were established in high schools for "educable" children, who were also emotionally disturbed.

The 1956-57 Annual Report of the Portland Public Schools indicates that some of the children in the remedial reading program were emotionally maladjusted and intellectually and socially immature. It would appear that some children with emotional difficulties were removed from the regular classroom to this program. Since the 1950's the school district has provided teachers for the Parry Center, a treatment facility for emotionally disturbed children. The Annual Report for Portland Public Schools, 1963-64, states that there were 46 emotionally disturbed children receiving instruction in their home from teachers provided by the public school.'s home instruction program.

The 1966-67 Annual Report indicates that Parkrose School District had a program for autistic and schizophrenic children and that some of the children came from the Portland school district. In 1970-71 the Portland school district had classes for emotionally disturbed children at Jackson High School, Abernathy, Arleta, Richmond and Fernwood grade schools.

In the 1974-75 school year, nine additional classrooms were established to serve the needs of the emotionally disturbed child. In Area I, individual classrooms were placed in Multnomah and Portsmouth Middle Schools and Collinsview elementary school. In Area II, Vernon, Scott and Lent elementary schools were chosen to house one classroom each. Data for thjs practicum was obtained from these three classrooms. In Area III, the three classrooms were located 
in Abernathy, Sellwood, and Sacajawea grade schools. These nine classrooms attempt to provide educational services for the emotionally handicapped child who might otherwise not have been served by the public school system. 
CHAPTER II

REVIEW OF THE LITERATURE

Nearly all special education programs involve change of behavior in one form on another. This emphasis on overt behavior change is particularly relevant for programs designed for the emotionally handicapped child. Literally hundreds of different practices and procedures have been introduced, designed to facilitate behavior change. What one elects to do depends on what he believes to be wrong in the first place; i.e. the analysis of a problem pre-determines what one deems a necessary remedy (Burban, Ford 1971). The selection of goals for a program is a function of one's theory of normal behavior development. Not only are there multiple ways to effect behavior change but it is widely recognized that treatment intervention can benefit some patients, actually harm others, and render still others relatively unaffected (Burban, Ford 1971). In terms of goals, the program director, as well as the researcher, needs to ask the question what is the goal of this program--symptorn removal, a fully-functioning person, restoration to a level of functioning prion to the advent of the behavioral difficulty, graduation from college, etc.? Nearly all cf the studies cited, whether dealing with identification, classroom models, treatment onientations, on behavion modification have struggled with the definition of goals, what to measure and in which instance is the measurement appropriate. 
Actual special education programs for emotionally disturbed children appear to fall into three categories: (1) holding actions, in which minimum achievement and performance demands are exerted until something happens, (2) quasi-therapeutic approaches in which the educative process is seen as primarily therapeutic (psychotherapy approach), (3) achievement oriented programs which focus on education and academic achievement, usually based on a theory of personality (Quay 1963). The special classes in Area II appear to fall in the second category, while also recognizing that an increase in academic achievement will eventually result in a greater sense of self-esteem. The philosophical underpinnings of the Area II program reside in the concept of mainstreaming currently in vogue. ${ }^{1}$ one of the major goals of the program is to return at least $75 \%$ of program students to their regular classroom by the end of the 1975 school year. In addition, Special Needs Center (Resource Room) teachers and aides are to maintain contact with each child's regular classroom teacher with the intention of actively involving the regular teacher in the planning for the reintegration of her particular pupil and to employ a specific prescriptive educational program for that child's continued social and academic growth.

Mainstreaming

Emphasis, today, in Oregon and across the nation is on mainstreaming on normalization. Fein (1973) discovered that the young child,

$I_{\text {Mainstreaming is the practice of enrolling exceptional children }}$ in classes with normal children. 
with poorly developed cognitive capacities, discovers that careful attentiveness to adults increases the likelihood of successful problem solving in some situations. If children enrolled in special programs interact with normal children the mainstreaming philosophy supposes an improvement in social skills and affect. In Canada, the Dell-Crest non-residential school program attempts to reach a goal of returning the emotionally disturbed child to his community school after about one year in the program (Buttimor 1973). Those who favor mainstreaming argue that children lose more than they gain in a self-contained special class. Shotel (Shotel, Iano, McGettigan 1972) states, however, that if integration is desirable then the attitude of regular classroom teachers is of major concern. It was found in this study that regular classroom teachers place less emphasis on personal and social adjustment than special education teachers in encouraging the low ability child to try harder. In this study a significantly greater percentage of experimental teachers (teachers with a resource room in their school) than control teachers were favorable toward integration into the regular classes with supportive resource room services. However, less than $50 \%$ of the experimental teachers expressed a favorable atiitude for the integration of the emotionally disturbed child into the regular classroom. It appears as though in the last twenty-five years the confusion as to the major purpose of special classes has not been resolved:

should their first aim be to ameliorate the condition of the children either by special tutoring with the hope of eventual return to regular classes or by special industrial 
training designed to prepare them for some kind of useful work after leaving school; or should the major emphasis be placed upon the relief given to the regular classes through withdrawal of the laggards. In theory, at least, the concept of equal educational opportunity for all led to the general acceptance of the idea of aid to the handicapped child as the major objective of the special class, but in the practical situation, the second of the two motives was likely to operate (Goodenough 1949).

Glavin, Quay, Annesley, Wery (1971) found that any intervention which removes the basic responsibility for the child from the hands of the regular class teacher serves to make reintegration of the child more difficult. Glavin emphasizes that a successful program must aim at upgrading academic skills as well as eliminating deviant behavior (GIavin, Quay, Wery 1971.). Cohen (1969) believes that classes for the emotionally disturbed are a response to a shortage of trained psychiatric and psychological personnel, ineffectiveness of individual therapy without additional environmental supports, failure of school programs in meeting needs of children who are different, and the demand of educators who want children who "don't fit" banned from regular classes. Meanwhile, the battle rages between efforts to mäinstream and non-stigmatize children in need of special education programs, and the effort to group these children homogeneously with professionals equipped to deal with their specific problems.

Warner, Thrapp, Walsh (1973) argue that of 36 children placed in an Educable Mentally Retarded class in Califonnia, 61\% Ii*ked their special class, $41 \%$ had no desine to be in any other class, $25.7 \%$ wanted to be in another class and $27.10 \%$ were undecided. Fewer than $10 \%$ pèrceived themselves as mentally retanded. Mckennan, Archie (1970) found that parents of children in special classes viewed the 
classes as a positive influence in their lives, welcomed the lack of daily calls from the regular classroom teacher, liked the special tutoring but disliked the separation of their children from regular children. Their children's perceptions were that of having a pleasant, positive experience. The majority of researchers in the area of effects of special classroom placement seem to agree that a return to the regular class is beneficial and that control of the special. program and reintegration process should be in the hands of the regular classroom teacher (Saunders, Tullio 1972; Camp 1967; Bisger 1964; Kounin 1964, 1968; Hewett 1968; Glavin 1971).

Although the philosophy underlying mainstreaming and the Area II program is difficult to fault, Vacc (1972) in a disturbing study for those committed to special education programs, found that if special classes have any advantages over regular classes for emotionally disturbed children, it exists only as long as the children remiain in the special program. Vacc states that "the final test of any special class program is the degree to which a child's improvement resulting from the special class procedure, is maintained after his return to a regular class". Vacc calls for more investigation of long term changes in achievement and overt behavior in emotionally handicapped children. Comparatively little research has been published regarding emotionally handicapped children in school settings, because the experimental literature on overt behavion change, achievement and social relations of school children is not easily applicable to treatment. Ensher (1973) is in agreement, stating that there is a 
need for comprehensive, longitudinal description along several dimensions of child and teacher behavior in evaluations of learning and emotional problems in children.

Identification

Educational concerns for the emotionally handicapped center around areas of definition of the label itself, identification of the emotionally disturbed child, curriculum, methods, teacher training, and administrative practices (Quay 1963). In regard to definiticn, a number of empirical studies (Quay 1966; Swjft, Feldman, Bratton 1972; Kohn, Rosman 1973; Register, LeBate 1972; Brody, Plutchik 1973) have shown that there are certain recurrent, observable symptoms of problem behavior in children and these symptoms tend to cluster into two major syndromes or symptom clusters: (1) acting out or "conduct problem", (2) withdrawn or "personality problem". In recent years emphasis in education has been on the early identification of children with learning and emotional problems. Various organizations like the Oregon Association of Children with Learning Disabilities have as a major goal, the education of the general population as well as school administrators, in terms of diagnosis of these children and corresponding special programs. Educators and researchers remain divided as to the advisability of wholesale adherence to early identification and diagnosis of children with multi-faceted problems. Behavioral problems and developmental phases do not occur in all children of the same chronological age at the same level. Unfortunately, our educational system is organized around 
chronological age as opposed to developmental age. Some questions for professionals concerned with learning and emotional problems are: at what age of development is a behavior pattern inappropriate, what test can accurately measure the degree of inappropriateness, how are individual differences in the child to be accounted for and how are individual differences in the examiner and the therapist or teacher to be standardized. Is defining a population with similar behavioral symptoms enough in order to stimulate or create remediation of that population's problems? In evaluating trial programs, how does the researcher incorporate individual differences in his theoretical formulations and research designs?

Keogh, Becker (1973) maintain that support for the importance of early identification comes from the physical disability on disease modes--an approach based on the following assumptions: (1) that the condition to be identified is seen as already existent in the child. (2) that this recognition carries a prescription for treatment (3) treatment of the disease will minimize compounding problems. Keogh, however, argues that in seeking identification of pre-school and kindergarten children with future learning failures, we are hypothesizing not confirming. How valid are the identifying or predictive measures; what are the implications of diagnostic data for remediation or educational intervention; do tenefits of early identifjcation outweigh possible damaging or negative effects of such recognition?

Oakland (1969) recommends that any school system which lacks comprehensive pupil evaluation services develop them only after care- 
ful consideration. He maintains that both the diagnostic etiological approach and the diagnostic remedial approach ${ }^{2}$ fail to examine important extra-personal variables such as curricula, teaching methods and materials, teacher and parental expectancy and peer and adult acceptance. These approaches also de-emphasize the child's strength. Diagnostic tests are notorious for their lack of adequate standardization (Oakland 1969) and often provide little direction to planning an educational program for the high risk child (Keogh, Becker 1973). On the other hand, schools are faced with increasing numbers of children whose behavion renders them ineligible to receive educationally reinforcing experjences (Stennett 1966). Informally, most classroom teachers and principals will quickly tell you which of the children have low skill levels, resulting in repetitive failure experiences. Our emphasis on scientific measurement and data does not allow for these subjective judgements to stand as the only criteria for placement of a child in special programs. Nor does the limited number of programs and trained professionals allow the indiscriminate placement of hundreds of children in slots designed for numbers usually under fifty. In response to this aspect of a complex problem, studies continue to emphasize various predictive measures for the assessment of the severity of learning and emotional problems.

Redl and Wallenberg (1959) list six pre-school tasks to be

${ }^{2}$ Diagnostic Etiological is a search for the cause of a problem; Diagnostic Remedial established a profile of a number of psychological and educational basic abilities to plan a treatment. 
mastered before a chila can be considered ready for an elementary school experience: (1) appreciation of reality (2) attitudes toward cuitural demands (3) attitudes toward panents and authorities (4) development of curiosity (5) formation of a conscience (6) social growth. A failure to complete any one of these tasks could become a basis for later school difficulties. Kohn, Martin, Rosman (1973) propose a measurement of two major dimensions of social-emotional functioning in the assessment of pre-school childnen: interestparticipation versus apathy-withdrawal and cooperation-compliance versus anger-defiance. Their particular Problem Checklist and Social Competence Scale appears to distinguish emotionally disturbed pre-school children from a normal population. It has been confirmed by Cowen (1973) that the negative consequences associated with early school dysfunction appear later in school with disproportionately high frequencies of maladaptive behavion. Galvin (1968) found that after four years, at least $30 \%$ of children classified as emotionally disturbed in grades two to five and who had received no intervention, were still emotionally disturbed. Menocaseino (1965) states that the frequency of emotional disturbance increases in children four years old and above.

Adequate research designed to document whether or not an unresponsive learning environment plays a part in the increase has not been done. An argument for early identification and the development of pre-school screening instruments appears warranted in terms of the conclusions of Stennett's study (1966): (1) $5-10 \%$ of children in elementary schools are emotionally hardicapped and need profession- 
al help (2) screening devices are adequate (3) a significant number of emotionally handicapped children fail to resolve their problems by themselves (4) the emotionally handicapped child tends to get progressively farther behind in academic achievement than his classmates. The following studies have in common the attempt to arrive at a definitive test or assessment procedure, with a high degree of reliability in identifying emotionally disturbed children: Spivach, Swift, Prewitt (1971)--children's responses to school demands are determined by a complex of factors, the numbers and types of which depend on grade level considered, child's family background and cultural milieu; Goldstein, Cary (1970)--any comprehensive attempt to predict school success should include an assessment of family background; Swift, Feldman, Bratton (1972)--understanding of classroom behaviors which influence learning are important to educational and mental health personnel, created the Devereaux Elementary School Behavion Rating Scaie; Graham, Rutter; George (1973)--a link exists between adverse temperament and adverse family attitudes; Rider (1973)--all mean scores of emotionally disturbed children on the Purdue Perceptual-Motor Survey, Southern California Sensory Integration test, and Reflex testing for Evaluation of Central Nervous System Development.were. lower than scores of normal children; Wagonseller (1973) the verbal IQ scale on WISC and the WRAT reading grade equivalent and WRA'T total mean spelling grade can differentiate between children with learning disabilities and the emotionally disturbed; Fisher (1969) boundary definiteness is a significant generalized 
predictor of classroom behaviox. ${ }^{3}$

Where does all this identifying data leave classroom teachers? Teachers expect the results of an appraisal of a child to be (1) credible (2) understandable (3) translatable into realistic remedial practices (Oakland 1969). On the other hand, Novack, Bonaventura (1973) see the classroom teacher as the key person in the detection of pupil behavior. Classroom teachers are increasingly being called upon to provide both diagnostic assessment and treatment for the child with emotional problems (Zive 1970; Miller 1972; Quay 1966; Maes 1966; Patrick 1965). The classroom teacher may be the key person in the initial detection of pupil maladantive behavion but the translation of data into realistic remedial practices requires the partnership of a psychological examiner, teacher, principal, school psychologist and the parents. Compounding the task and responsibility of the classroom teachers is Keogh's (1973) argument that the identification of a given child as high risk for school failure is in essence a prediction that he will fail or have problems in the existing school program; to place him in the program which has been predefined as failure producing for him without modifying that program puts the child in double jeopardy and maximizes the possibility of a self-fulfilling prophesy.

Teacher Intervention

The regular classroom teachen is increasingly called upon to

3 Wetter, French (1973) computed product moment coefficients of correlation between specific PIAT and WRAT subtest scores and found all coefficients of correlation to be significant at the $1 \%$ level. 
provide services for which she is not adequately trained (Cruickshank 1958). When deviant behavior appears in her classroom she is called upon to don the cap of various professions: social worker, who analyzes family constellations (IIIlman 1972); child psychologist, trying to assess a child's level of development; behaviorist, attempting to ascertain the necessary concommitants for the motivation of a particular child; psychiatrist, determining the child's reality testing and defense mechanisms; and administrator, developing programs (mostly informal and outside of her own classroom) which may enable a child to respond to his ecucational environment. Altman (1973) has found that self-esteem and academic success are positively correlated. Yet, it can be seen that the regular ciassroom teacher has little time, without additional resources, to ensure the academic success and therefore, sense of self-esteem, for. every individual child in her class. A number of different programs have developed in response to the teachers" cries for help. "Special. education, as discussed earlier in this chapter, has devised various programs. However, Ouay (1968) feels that there are two basic weaknesses in these programs: (1) current grouping practices force the educator to deal with an heterogeneous pojulation in regand to abilities and disabilities for classroom learning (2) special education programs are rarely designed specifically to improve academic competence of the child.

What is needed to produce a truly effective special education is the development of a conceptual framework which permits the assessment of exceptional children on educationally relevant variables, their grouping according to similarities of dysfunction on these variables, and the development 
of a classroom teaching technology aimed at correction of those deficiencies (Quay 1968).

Various classroom techniques have developed around the theory that many children are amenable to a special class program which rests on an extensive, continuous (multi-disciplinary) psychosocialeducational diagnosis of each child's strengths and shortcomings; and which presents an ordered set of clear cut opportunities, controls, and limits administered in a non-punitive manner and geared to diagnostic findings (Allen 1970; Snapp 1973; Hewett 1968; Vander Kolk 1973; Chazan 1973; Simeonsson 1973; Brown 1968; Knoblack 1973; Weinstein 1968; Brown 1967; Radin 1968; Winkler 1966). A common denominator in ali of these classroom prograns is the child's eventual. return to a regular classroom, where his individualized prescriptive educational program will be integrated with programs the class teacher is currently following. In all studies attempting to ascertain change in pupils' behavior and/or self-esteem the criteria of pupil change has often not adequately been defined and longitudinal evidence for the effectiveness of intervention programs is lacking (Johnson, Black 1968).

Classroom Methods

The Council for Exceptional Children (Johnson, Black 1968) also found a trend toward behavior-modification techniques in many of the special education programs. Each of the Area II classrooms for the emotionally handicapped is employing some form of reinforcement based on the theory of behavior modification. The emphasis, however, is on an individual's response to tasks and requests 
appropriate to his level. of development and not necessarily those behaviors related to his teacher's hopes and expectations of ideal behavior (MacMillan 1970). Behavioral therapy techniques have been found useful in helping parents cope with emotionally disturbed children (Wiltz 1973). Research in behavior theory has provided us with some key concepts: the more feedback provided for error and correct responses, the more efficient learning and performance will be as measured by academic response rate (Walker 1972). Stone (I969) has found that methods which rely heavily on verbalized social approach will meet with little success in treating the emotionally disturbed child. Lorber (1966) has found that the socially ineffective child continues any overt activities that receive the social attention he is seeking and therefore, manifests poor behavior in the classroom. Behavion which when broken down into its component parts may be amenable to change through various schedules of reinforcement. Special education teachers, while not explicitly behaviorists, have gained some worthwhile tools for changing external behavior which contribute to peer and teacher reactions which in turn contribute to internalized negative self-concepts. If the teacher is cognizant of MacMillan's (1970) cautions in the use of behavion therapy she can appropriately incorporate various techniques into her change program.

Summary

A basic assumption underlying the establishment of the Area II program for emotionally disturbed children is that the schools have 
an obligation to educate all of our children. The education of emotionally disturbed children is a complex and difficult task, requiring the cooperation of many different professionals within both the school and the community. However, being given the responsibility for educ-ating emotionally disturbed children does not automatically mean that programs will be realistic, beneficial or well-run.

It is our opinion that the quasi-therapeutic approach (Quay 1963) elected by Area IT is a sound one. The emphasis on improving academic as well as social skill areas appears to be sound given the goal of returning these children to their reguiar classroom. Although mainstreaming has its opponents, it appears that the Federal Bureau of Education for the Handicapped has not only formulated guidelines and a philosophical statement in support of mainstreaming but has made the practice a prerequisite for school districts and other agencies to receive federal money for special education (Portland Oregonian article, March 1, 1975).

There is no question that with mainstreaming a great deal of responsibility for educating exceptional children reverts from the special education teacher to the regular classroom teacher. Area II has recognized that the regular teacher needs support and back-up services. The SNC teachers have established rappont, in most cases, with the teachers of the children in the program and have become advocates for these problem children (Shotel, Iano, McGettigan 1971). In addition, each child has specific educational tasks designed to achieve academic and social skill growth. These programs are stated in terms understandable to any other teacher. A great deal of effort 
has been spent in order to retain the regular classroom teachers' autonomy and responsibility for any given child in order to facilitate that child's reintegration.

The weaknesses in the Area II program involve the participation of the parents of these disturbed children. A number of contacts have been made with the parents but there appears to be no formal program designed to integrate home and school performance and behavioral goals. Many of these parents would benefit from education concerning their child's problem and support for the implementation of new parenting techniques. At this time, there are no plans for a Iongitudinal study (Vacc 1972) and it will be difficult, for reasons mentioned previously, to truly assess the effects of this program without such a study. We need to know what happens to these chizdren once they are reintegrated into the regular classroom.

In addition, the SNC teachers and aides are dealing with a. heterogeneous population (Quay 1968). Emotionally disturbed children are not a uniform set of syndromes. Each child needs an individual assessment and an individual treatment plan. It is very difficult to adequately define the criteria for pupil change. Given these weaknesses, the program in Area II has certainly been designed with an awareness of the problems dealt with in the literature in regand to the establishment of an effective change-producing program. 
CHAPTER III

METHODOLOGY

$\underline{\text { Research Design }}$

The original goals for the Area II Frogram For The Emotionally Handicapped included the following objectives:

1. To have at least $75 \%$ of the students served spending $90 \%$ of their school time in regular class activities by June, 1975 . 2. To increase by $80 \%$ the frequency of task oriented behaviors in children 'served.

3. To decrease by $75 \%$ the frequency of at least one behavior which interferes with learning in the children served. 4. To maintain or increase proficiency in academic skills (reading, writing, spelling, mathematics) in the children being served.

5. To maintain or increase proficiency in social skills (group work, seeking alternatives, relationship to peers and aduits) in children being served. 6. To enroll at least forty-five students by the end of the school year 1974-75.

This proposal was presented to us in July, 1974 and we were asked to evaluate the program in terms of these goals. Our research design was intended to achieve a maximum degree of internal and external validity. However, it was subject to the 
constraint that only those measurements which the Diagnostic Psychological Examiner used for children in the program were accessible to us. Since children for this program were not chosen randomly we decided to use a non-randomized control group pre-test, post-test design (Issac 1971). A control group would insure against mistaking the effects of history, pre-testing, maturation, and instrumentation for the main effect of treatment or non-treatment. In the absence of rardomization, however, the possibility always exists that some critical difference, not reflected in the pre-test, is operating to contaminate the post-test data. Since it was not possible to have randomization, it was not possible to have a valid application of analysis of co-variance (Issac 1971). With this design external validity can be questioned in terms of interaction of pre-testing and treatment, and the interaction of selection and treatment.

It was our hope that the regular classroom teachers of students in the comparison group would not be aware of their students' participation in this evaluation. We did not attempt to match subjects to form pairs for later comparison, because of the arbitrariness of deciding on which variables to base the matching. In addition, there is a problem of statistical regression when matching subjects or groups which turn out to represent different populations with respect to matching variables.

The two sample populations of this study were to be all children enrolled in the Area II program-for the emotionally handicapped, and a comparison group chosen from schools similar in demographic description to those in the program. This comparison group was proposed to 
be selected in one of two ways. By the first of these methods, a school administrator would submit guidelines to teachers for student referrals to the program and from that list the diagnostic psychologist would detemine which children would qualify for the program. By the second of these methods children working with members of the Area II Prescriptive Education Personnel, because of emotional handicaps, would form the pool from which random selection would occur. For either method of selection, students in this group would include only students who attend classes at schools other than Lent, Scott and Vernon Schools, where the subject classrooms are located. Once the comparison group was chosen, two additional students were to be chosen at random from each classroom attended by an emotionally handicapped child. The referral guidelines for the students in the comparison group were to have been sent to all Area II schools by : June 1974 .

By September 1974, it was evident that the Northwest Regional Laboratory, retained as consultants, had determined to revise the original proposal. Anong other items, objective number three was deleted and an attempt was made to define those behaviors which teachers were to measure. A revision in terms of checklists for objective number four was implemented. This revised proposal was given to us in January 1975. In addition, no referral guidelines for the comparison group were sent out to the schools until nctober 1974. This made it impossible to include the two additional students chosen at random from each classroom attended by an emotionally handicapped child, since there would not be enough time to administer the Peabody 
Individual Achievement Test to all children in the school program. The comparison group may well have been a biased sample of the emotionally handicapped population in Area II, since not all schools returned referral forms, before october 31 . It was originally anticipated that there would be forty-five students in the Area II program for emotionally handicapped children and we wanted an equal number in the comparison group. Fonty referrals were received and therefore, we could not randomly select our comparison group. The diagnostic psychologist could not determine which of these students could qualify for the program because of her involvement in the screening of those children to be placed in the actual treatment program.

Our original null hypothesis was that there is no significant difference between the control and study groups with respect to variables measured, including indices of academic skills in reading, speliing and mathematics; increased frequency of task oriented behavions; increase in quality and number of social skill acts including choosing alternatives, work in groups, peer and adult relationships, participation of parents.

The measuring instruments used by the Diagnostic Psychological Examiner for children in the enotionally handicapped classroom were the Peabody Individual Achievement Test pre and post-tests, timed behavior observations prior to placement in the class, I. O.'X. SelfAppraisal Inventory test, the Hewitt Behavior Checklist and the Hill-Walker behavion checklist introduced in December 1974. We originally decided to use a pre and post-test P. I. A. T. and the I. O. X. Self- 
Appraisal Irventory pre and post-test, for children in the comparison group. In discussing these tests with an Area II school administrator, we were questioned about the use of the Self-Appraisal Inventory. Philosophically, a measure of self-concept depends on a number of rather subjective variables, and this particulan administrator felt that measures of self-concept were basically unreliable. In addition to this, Oregon Law requires that parental permission be obtained for administering any psychological test. We felt that obtaining the parental permission for the forty children in the comparison group would lead to confusion on the part of the parents and teachers in terms of the reason for the testing. Therefore, we decided to substitute the Hewitt Behavion Checklist for the self-concept scale on the assumption that an inprovement in classroom benavion would reflect an improved self-concept.

Measuring Instruments

The standardization sample for the Peabody Individual Achievement Test was drawn from a national population of school children in the United States. The P. I. A. T. was standardized over the period from February 10 through May 15, 1969. The P. I. A. T. was designed as an individually-administered test. Individually administered instruments enable an examiner to establish a personal relationship with the subject and thus elicit a more optimal performance, especially with an individual who is less motivated toward school achievement. The P. I. A. T. is a wide range instrument extending from kindergarten through high school, with the items arranged in order of difficulty. 
The P. I. A. T. was designed to be a screening test which could be quickly administered and scored---typically taking from thirty to forty minutes. It is an untimed "power" test. A premium on speed would have been a handicap for many of the types of individuals most likely to be referred for evaluation, the underachieving, the disadvantaged, and the handicapped.

Frank M. Hewitt, associate professor of education and psychiatry, University of California, Los Angeles, has devised an educational assessment device for emotionally disturbed children in schools. Hewitt feels that psychosis, neurotic traits, behavior problems, and other social-emotional difficulties can be viewed as failures to pay attention, respond, follow directions, explore, furction appropriately in a social context, acquire intellectual and adaptive skills, and develop a self-motivation for learning. (Hewitt 1968). ${ }^{1}$ His purpose was to introduce the use of a developmental sequence as an educational assessment device, assuming that differential treatment programs would be employed for children scoring poorly in any of the six areas (attention, response, exploratory, social, mastery, achievement). His purpose was to insure that diagnostic information was translated into meaningful treatment programs, which could be directly employed by the classroom teacher.

In an attempt to shorten the check list for the purpose of greater teacher acceptance, reward categories were omitted for all

${ }^{1}$ See Appendix page 69. 
levels and question three under attention was omitted. ${ }^{2}$

Hypotheses

Children enrolled in Portland public schools Area II program for the emotionally handicapped child will make a statistically significant greater gain in positive behavior, as measured by the Hewitt Behavion Checklist, than those children in the comparison group who are not in the treatment program. Children whose parents have a high number of contacts with the school, will have more positive scores on the Hewitt Behavior Checklist, than those childrer whose parents have a low number of contacts with the schools. Those children in the treatment and comparison group with higher mathematics scores on the P. I. A. T. will have higher scores on the Hewitt Behavior Checklist. Our third hypothesis is based on an assumption we made after reading Stone's (1964) study. He found a positive correlation between low math sub-test scores on the Wide Range Achievement Test and children who were emotionally disturbed. We therefore assumed that in a population of emotionally disturbed children that those children who scored below the extended median of 90 on the math subtest of the P. I. A. T. would also score below the extended median of 1.90 on the Hewitt Behavior checklist.

Null Hypothesis

There is no significant difference between the comparison and treatment groups with respect to the variables measured, including

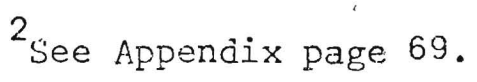


indices of positive behavior as measured by the Hewitt Behavior Checklist, number of parental contacts with the school, and mathematics scores obtained on the F. I. A. T.

Operational Definitions

A high score on the P. I. A. T. mathematics sub-test was considered to be any score over 90. This scone of 90 represents the extended median for the comparison and treatment groups together. A high score on the Hewitt Behavior Checklist was considered to be any scone over 1.90. A score of 1.90 represents the extended median for the comparison and treatment groups together. A parent contact with the school was considered to be any communication either by phone or in person whether parent initiated or school initiated.

Data Collection

The selection of the population of the special classes in the Area II program for the emotionaliy handicapped was made in the following manner:

1. A form entitled "Preliminary Referral for the Emotionally Handicapped Program" was sent to all elementany schools in Area II in May $1974 .^{3}$

2. This referral form was returned to the Area II district office in Jure 1974.

3. During the first week of September a conference was held to select those children from the referrals who might enter the ${ }^{3}$ See Appendix page 67. 
special program. The selections were made by the program director, and the Diagnostic Psychological Examiner (D.P.E.) and the principals of Lent, Scott and Vernon schools.

4. The D. P. E. obtained parental permission to conduct an evaluation of each child.

5. Prior to entrance into the Special Needs Center, the D.P.E. observed the seiected children in their regular classroom setting. This included three timed classroom observations, measures of achievement and personal adjustment (P.I.A.T. and Self Appraisal Inventory) and a new review of school and community agency records. The D.P.E. held a semi-structured interview with the child. When the evaluation was completed, the D.P.E. arranged a staffing to include the S.N.C. team (classroom teacher, S.N.C. teacher, and teacher aid, principal, and D.P.E.) at which a decision regarding S.N.C. placement was made.

6. Following the staffing the D.P.E. met with parents to obtain the necessary permission forms and to insure that the child received a physical examination and a psychiatric evaluation, if indicated. The D.P.E. established and maintained contact with the parents and physician as needed.

7. Until physical examination was completed the S.N.C. and classroom teacher prepared the initial educational program for the child.

It was anticipated that there would eventually be forty-five children enrolled in the Area II program. At the time of our data collection, twenty-two children had been selected. 
We did not take part in the selection process for the treatment group.

During the screening process we were attempting to obtain referrals for the comparison group. We also attended meetings involving program staff and administrators. By October 3l, we had obtained referrals from seven schools in Area II. A letter of introduction was given to us by the Area II Specialist in Testing and Evaluation. We divided the final thirty-eight referrals by schools and administered the P.I.A.T. to all children in this group by November 14. At the time of the testing of each child; a Hewitt Behavior Checklist was filled out by that student's classroom teacher. Teachers were not told that their students were involved in evaluation of the Area II program for the emotionally handicapped. If teachers asked about. the purpose of testing and the checklist, we told them that Area II was interested in the number of children in the District who might be eligible for a special program. A form requesting the number of parent contacts; Prescriptive Education Personnel interventions, and contacts with other agencies, was left with principals of schools in the comparison group. This was done at the request of an Area II administrator in an attempt to track the types of interventions used with emotionally handicapped children in a regujar classroom. During the first week in March, regular classroom teachers for both the comparison and treatment groups were asked to fill out the Hewitt Behavior Checklist. A P.I.A.T. post-test was not given to the comparison group as originally planned, since a P.I.A.T. post-test would not be administered by the D.P.E. to the treatment group prior 
to May 23, 1375, the due date of our report.

In summary, our research design was changed from the evaluation of original program goals and objectives to an evaluation of program success based on Hewitt's Behavior Checklist. 
CHAPTER IV

FINDINGS

Before discussing our findings we would like to describe our samples. There were 18 children for whom we obtained complete data in the treatment group, 16 boys and 2 girls with a mean age of 9 years 3 months. As a group they achieved a mean standard score of 88 on the P.I.A.T., with a range from 65 to 104. The P.I.A.T. was administered once in November 1974. In the comparison group there were 28 boys and 6 girls for a total of 34 students for whom we obtained complete data, with a mean age of 8 years 9 months. Their mean standard score on the P.I.A.T. was 93 with a range from 65 to 105. The comparison group was made up of children from the following seven schools; Whitman, Woodmere, Marysville, Wilcox, Glenhaven, Jason Lee and Rose City. A test of the significance of the difference between two sample proportions for the sex distributions indicated no significant difference between the two groups at the .05 significance level. Both the treatment and comparison group obtained a mean score of 2.08 on the first Hewitt Behavior Checklist administered in November 1974. The H.B.C. test scores were not significantly different, but the treatment group was about six months older than the comparison group.

Hypotheses

Our first hypothesis was that children enrolled in Portland 
Public Schools Area II program for the emotionally handicapped child will make a statistically significant greater gain in positive behavior meausred by the Hewitt Behavior Checklist than those children in the comparison group who are not in the treatment program. We will see that oun results did not support this hypothesis.

In determining improvement from pre-test to post-test as measured by the Hewitt Behavior Checklist, we assigned scores from 1 to 3 , for each question; "l" was assigned to less positive behavions and "3" to more positive behaviors. A mean score was obtained for each child by dividing the total number of points by the number of items answered. A group mean was then computed. This group mean on the H.B.C. pre-test given in November 1974, was 2.08 for the treatinent and comparison groups. On the H.B.C. post-test given in Manch 1975 the group mean for the treatment group was 2.31; for the comparison group the group mean was 2.34 .

We used a one tail t-test to test the hypothesis that there was significant improvement from pre-test to post-test in each of the two groups. For the comparison group the calculated value of $t$ was 2.24 with 66 degrees of freedom and for the treatment group the calculated value of the $t$ was 2.09 with 34 degrees of freedom. In each group there was significant improvement at the .05 level of significance. We then used a t-test to test the hypothesis that the improvement in the treatment group was significantly better than improvement in the comparison group. Our results do not suppont this hypothesis. The calculated value of $t$ was .245 with 50 degrees of freedom. This is much below the critical $t$ value of 1.68 that would be needed for 
rejection of the null hypothesis at the .05 significance level.

Our second hypothesis was that children whose parents have a high number of contacts with the school will have more positive scores on the H.B.C. than those children whose parents have a low number of contacts with the school. Our results did not support this hypothesis.

The number of parent contacts was not available for all children in either of the two groups. The number of children for whom parent contacts were recorded in the comparison group was 30 . The number for the treatment group was 18. Parent contacts included consultation with the D.P.E., the teacher, and any other school administrator or personnel. The total number of parent contacts for both treatment and comparison groups was 424. We considered 8 or more parent contacts as a high number and 7 or less as a low number, based on the extended median. We considered 2.36 and above as a high score on the H.B.C, and 2.35 and below as a low score. We used a chi-square to test the hypothesis that a high number of parent contacts would be associated with a high positive score on the H.B.C. We calculated a corrected chi-square of .0248 with 1 degree of freedom and a total $\mathrm{N}$ of 48. This is not significant at .05 level of significance. Therefore, for this population there is no association between a high number of parent contacts with the school and a high score on the H.B.C.

Our third hypothesis was that children in the treatment and comparison group with high math scores on the mathematics subtest of the P.I.A.T. would have higher scores on the H.B.C. pre-test. Fon 
our population a standard score of 90 and above on the P.I.A.T. math subtest was considered high, and a score of 89 or below was considered low; based on the extended median, 1.90 or above were considered high scores on the H.B.C. and scores of 1.89 or below were considered low scores, based on the extended median. We used a chi-square to test the hypothesis and obtained a corrected chi-square of .657 with 1 degree of freedom and a total $N$ of 51 . This is not significant at the .05 level. Therefore, for this population there is no significant association between a high score on the P.I.A.T. math subtest and a high score on the H.B.C.

As stated earlier, an Area II school administrator had requested that we track any interventions occurring for children in the comparison group. Therefore, we left a form for each child with principals of each school in the comparison group. Unfortunately, very few of these forms reached the teachers (or if they did reach the teachers, they were not adequately filled out). We have information for 18 children concerning various types of intervention. Two of the children were prescribed medication, 6 are working with school social workers, 4 have had psychological testing through the P.R.E.P. team and one had a PREP team consultation with the classroom teacher, 1 was returned to his former neighborhood school, I was transferred to another teacher, same grade in the same school, I of those working with the school social worker was returned to a lower grade, I received speech therapy from Portland State University and I was tutored individually by a work-study student from Portland State. 
Discussion

It is tempting to explain the significant improvement in the reported behavion of the comparison group in terms of the variety and degree of interventions for the members of that group as just described.

A number of other factors such as range of teacher skill and experience in relating to emotionally handicapped children, socioeconomic level of parents, attitudes of each school's administrators towards disruptive children and the children's maturation itself might also account for their improvement. In addition, the Hewitt Behavion Checklist as constructed for this study appears to have been difficult for the classroom teachers to understand. Although the instrument may result in a prescriptive educational treatment plan for an individual child, it does not allow for enough latitude in scoring a wide range of disturbed behaviors. We suspect that the score of 2 represents a wide variety of behavional responses to educational situations.

Although the post-test scores on the Hewitt Behavion Checklist showed no significant difference between the comparison group and the treatment group we feel that any improvement in these emotionaliy handicapped children is important in their social and emotional. growth. Based on this study alone, it would be unfortunate to conclude that the special education program was of no greater significance in influencing positive behavior change than a regular classroom placement. It would be appropriate to question the validity of the 
Hewitt Behavior Checklist as a measuring instrument for children with emotional handicaps. We have no data upon which to base a measure of association between scores on the H.B.C. and actual behavion exhibited in the classroom. This relationship needs to be explored before accepting the Hewitt Checklist as a valid measure of pupil behavior.

The fact that there was no significant association between the number of parent contacts with the school and a high score on the Hewitt Behavion Checklist can, possibly, be accounted for by the inconsistency of recording procedures. Some teachers of the comparison group kept very conscientious records and others did not. The parent contacts as recorded could not be differentiated as to those initiated by the school and those initiated by the parent, contrary to the intent of the oniginal design. Nor were there any distinctions made between parental phone contacts, consultations with the teacher, consultations with the PREP staff, and actual parental participation in the classroom. No test was done on the underlying hypothesis that parental contact with the schools can be equated with parental concern for or involvement with their children, or on differential reasons for contacts.

In summary, the data we gathered forced us to reject all three of our original hypotheses. The data do, however, leave us with several factors to consider. Among them are the validity and reliability of our measuring instmuments, the representativeness of our population, uncontrolled variables such as maturation, variations in teaching and school environment, and variations in degree of 
behaviors considered to be maladaptive.

Summary

1. Both the experimental and comparison groups improved significantly in behavior.

2. There was no significant difference between groups in degree of improvement.

3. The number of parent/school contacts is unrelated to our measurement of overall behavioral change.

4. For our population of emotionally disturbed children, there was no significant association between high math subtest scores on the P.I.A.T. and high scores on the Hewitt Behavior Checklist. 


\section{CHAPTER V}

\section{CONCLUSION}

A possible weakness of our study may liee in the unknown characteristics of our measuring instruments. As stated before, the Hewitt Behavior Checklist is not a standardized instrument and has not been formally tested for validity or reliability. The teachers had difficulty in numerically describing (scale 1-3) specific classroom behaviors. They had the most difficulty in answering the explonatory, social and mastery categories. We chose the Hewitt Behavior Checklist as a measuring instrument because both the D.P.E. and we thought it would be a valid instrument and because we were requested not to use measuring instruments for the treatment group which were not being used in the screening process.

Lester Mann (1971) insists that "whether calipers are used on a skull on pencils on test profiles, it is still phrenology that is being practiced when the measurements are confused with and identified as processes". Mann lists nine assumptions of psycho-educational approaches:

...that differential psychoeducational tests can appropriately distinguish one group of handicapped individuals from another and from individuals who aren't handicapped.

...that these tests can effectively differentiate specific areas and sub-areas of functioning. 
...that the tests measure undenlying on basic abilities or functions of the testee.

...that the tests appropriately assess strengths and weaknesses in the underlying abilities which they are assessing.

...that the tests assess processes and abilities identifiable with the names of the tests and subjects that presumably measure them.

...that identification is the major or most important ability parameters in the domain being assessed.

...that processes or functions identified by the tests are ones toward which specific training can and should be directed.

...that tests can be used to program for children more effectively than traditional approaches to evaluation.

...that programs of differential ability training are more effective than global programs directed in traditional form toward curricular accomplishments (Mann 1970).

Although Mann may overstate the problems of psychometrics, his concerns require carefuI consideration by any researcher or educationist involved with children placed in a special education program on the basis of screening test measurements. In this study his assumptions are all untested. Each individual who uses a measurement 
tool must recognize that instruments inherent biases. In forming a composite index of behavion rather than taking components of the test, we may have assumed a test consistency which is unwarranted. We believe, on the basis of the condict of our study, that the Hewitt Behavior Checklist may not be an appropriate device. for measuring the classroom benavior of emotionally-disturbed children. The categories appeared to be ambiguous for the teachers who were trying to rate behaviors seen in the classroom. Having only three choices per item may not allow for wide enough range of describing behavior. Other assessment devices, among them, the Hill-walker Behavior Checklist and Social Competance Scale, and the Devereux Child Behavior Rating Scale, may offer better prospects.

The Peabody Individual Achievement Test, in contrast, is a standardized test of proven reliability and validity. Its results should not be viewed as binding for the duration of a child's school life, but the test can be viewed as an additional source of information concerning the level of educational achievement. This test, like any other, needs to be used in conjunction with the classroom teachers' assessment of a given child's level of academic functioning. The P.I.A.T. allowed us to establish rapport with children who were threatened by any other form of testing. Its use in the screening of children for the Area II special classrooms for the emotionally handicapped is, in our opinion, appropriate.

The heterogeneity of our sample for this study is consistent with the general lack of homogeneity in children labeled emotionally handicapped. Some of the children in our comparison group exhibited 
behaviors that could be classified as perceptual-motor dysfunction on learning disorders. On the whole, there is little question that the children in both groups are not functioning at optimal level in a regular classroom, We previously mentioned the possible bias in our sample. This bias could be controlled in future studies by allowing sufficient time for the administrative process to obtain students in sufficient numbers to allow for random selection. In a field study such as this it is difficult to control all intervening variables. Many of these variables were not measured in our study. Temporal measures over a longer period might or might not make a difference.

Inplications of Study

Our data indicate that there is no statistically significant difference in improvement in behavior between the treatment group and comparison group. It would be a mistake to conclude, however, that the special program for the emotionally disturbed is or is not producing substantial gains in both social and academic skills not measured. Each of the three S.N.C. classrooms provides a supportive environment for children who perceive themselves as being school failures. Actual behavions dealt with in these classes range from infantile temper tantrums, with kicking, yelling, swearing, crying, to physical assaults on other students and school personnel. No child came to the special classroom able to attend to a task. for a time sufficient to complete it. These children's anger expresses their frustration with previous and current failures in the school setting. There is no doubt that the task of educating these children requires a 
great deal of patience, skill and cost. From personal obsenvations in the three classrooms at scott, Vernon and Lent, it is evident that progress, however small, is being made with many emotionally handicapped children. Because of the problems in measuring instruments and original design of this study it would be inappropriate to base any decision concerning the value and continuation of the program solely on the results of this study. Quite apart from gains or losses in the experimental group, there are other values to be taken into consideration.

Recommendations

It is often asserted in the literature that studies evaluating special education programs need to be longitudinal and of broad scope. Vacc (1972) raises pertinent questions about the long term effects of special education programs.

We recommend:

...that the children in both our comparison and treatment groups be included in a Iongitudinal study.

...that the Hewitt Bchavior Checklist not be used as a measurement of children's classroom behavion without careful consideration of purpose and suitability.

...that a study designed to prove the success of this program in terms of the original goals and their achievement or lack of achievement should be done so that questions concerning future funding can be answered. 
...that a study of parents of these children involved in the program be undertaken and that it include a reliable measure of the influence of parental involvement on improvement or lack of improvement exhibited by thein children in the classroom.

...that our study be repeated, with the substitution of the Hill-Walker Behavior Checklist or other inventories for the Hewitt Behavior Checklist and with random selection of children in the comparison proup. Enough time should be allowed for an interval of at least six months between the pre and post tests on the Hill-Walker and the P.I.A.T. In conclusion, we wish to stress that improvement in behavion or any of the social academic skills needs to be assessed ir terms of where the individual began. Both groups of emotionally handicapped children made significant gains in behavior as measured by the H.B.C. Although the treatment group did not make statistically significant improvement in behavion as compared to the comparison group, the fact that emotionally handicapped children can make positive behavior gains in a school setting is important for these children. Any gain, no matter how small, may be crucial for his sense of self-esteem and his interaction with teachers, peers and parents. 
SELECTED BIBLIOGRAPHY

Annual Repont, Portland Public Schools, 1965-1972. .

Anchives, Portiand Public Schools, 1900-1956, Area II.

Allen, Thomas W. 1970. "The Evaluation of a Progran of Special Classes For 'Disruptive Children' in an Urban School System", Community Mental Health Journal, V. 6 (4), Aug., 276-284.

Altman, H.A., Scollon, J. 1973. "Influence of Process Variables in Self--Esteem", Psychology, V. 10 (2), May, 37-43.

Barlow, Bruce 1966. "A Program of Preparation for Teachers of Disturbed Children", Exceptional Children, V. 32 (7), March, 455-461.

1966. "The Emotionally and Socially Handicapped", Review of Educational Research, V. 26 (I), Feb., 120-133.

Barr, Karen L., MicDowell, Richand 1972. "Comparison of Learning Disabied and Emotionally Disturbed Children on Three Deviant Classroom Behaviors", Exceptional Children, V. 39 (1), Sept., $60-62$.

Bergin, Allen, Garfield, Sol L. 1971. Handbook of Psychotherapy and Behavior Change: An Empinical Analvsis, John Wiley \& Sons, New Yonk.

Bisger, Jay I., Kahn, C., Frazee, Vernon 1964. "Special Classes for Emotionally Disturbed Children", American Jounnal of Orthopsychiatry, V. 34 (14), July, 697-704.

Bledsoe, Joseph 1973. "Sex Differences in Self-Concept: Fact or Artifact", Psychological Reports, V. 32 (3), 1253-54.

Bower, Eli, Wickman, E.K. 1969. Children's Behavior and Teacher's Attitudes, Springfield Fress, Illinois.

Brody, Charles, Plutchik, Robert 1373. "Personality and Problem Behavior of Third-Grade Children in Regular Classes", Psychology in the Schools, V. 10 (2), April, 196-99.

Brown, Edwin, Chields, Eloise 1967. "Results with Systematic Suspension: A Guidance Technique to Help Children Develop SelfControl in Public School Classrooms", Jounnal of Special Education, V. 1. (4), Sumimer, 425-437. 
Brown, Saul L. 1968. "Co-ordinating Professional Efforts for Children with School Problems", Children, V. 15 (6), Nov., 214-218.

Bullock, Lyndal M., Brown, R. Keith 1972. "Behavional Dimensions of Emotionally Disturbed Children", Exceptional Children, V. 38 (9), May, 7'+0-41.

Burban, Hugh, Ford, Donald H. 1971. "Some Historical and Conceptual Perspectives on Psychotherapy and Behavion Change". Handbook of Psychothenapv and Behavior Change: An Empirical Analysis, Ed. Bergin, Alten, Garfield, Sol L., Tohn Wiley E Sons, New York, 1971 .

Buttimor, John 1973. "A Total Program for Helping Emotionally Disturbed Children", Canada's Mental Health, V. 21 (2), Mar., $17-23$.

Camp, William L. 1967. "A Successful Classroom Program for Emotionally Disturbed Children", Training School Bulletin, V. 64 (1), May, 31-39.

Chazan, Maurice 1973. "Special Education for Maladjusted Children and Adolescents in Norway", Journal of Child Psychology and Psychiatry and Allied Disciplines, V. 14 (1), Mar. 57-69.

Cohen, Shirley 1969. "Problems and Possibilities of the Special Class For Emotionally Disturbed Children", Psvchology in the Schools, V. 5 (4), 410-14.

Cowen, Emory L. 1973. "Long-Term Follow-up of Early Detected Vulnerable Children", Journal of Consulting and Clinical Psychology, V. $4.2(3)$, Dec., $438-446$.

Cruickshank, William, Johnson, G. Orville 1958. Education of Exceptional Children and Youth, Prentice-Hall Inc., Englewood Cliffs, New Jersey.

Cruickshank, WiJliam, Baul, James, Junkala, John 1969. Misfits in the Public Schools, Syracuse University Press, New York.

Cruickshark, William 1970. "Learning and Physical Environment: the Necessity for Research and Research Design", Exceptional Childrer, V. 37 (4), Dec., 261-8.

Csapo, Many 1973. "Parent-teacher Intervention with Inappropriate Eehavion", Elementary School Guidance and Counseling, V. 36

(2), Mar., $198-204$.

Douglas, J.W. 1966. "School Progress of Nervous and Troublesome Children", British Journal of Psychiatry, V. 112 (492), 11151116. 
Ensher, Gail L. 1973. "Clinical Studies of Teachers and Children in Selected Public School Educable Special Classes", Training School Bulletin, V. 70 (2), Aug., 93-105.

Fein, Greta 1973. "The Effect of Chronological Age and Model Reward on Imitative Behavior", Developmental Psychology, V. 9 (3), Nov., 283-89.

Fisher, Rhoda Lee 1968. "Classroom Behavion and the Body Image Boundarv", Journal of Projective Technique, V. 32, Oct., 45052 .

Fuller, Gerald 1965. "The Objective Measurement of Perception in Determining Personality Disorganization Among Children", Journal of Clinical Psychology, V. 2l (3), July, 305-08.

Galvin, John P. 1968. "Spontaneous Improvement in Emotionally Disturbed Children", Dissertation Abstracts, V. 28, 3503A, Mar.

Galvin, John P., Quay, H.C., Werny, John S. 1971. "Behavioral and Academic Gains of Conduct Problem Children in Different Classroom Settings", Exceptional Children, V. 37 (6), Feb.

Galvir, John F., Quay, Herbent C., Anneslev, Frederick, Werry, John S. 1971. "An Experimental Resource Room for Behavior Problem Children", Exceptional Children, V. 38 (2), Oct., 131-37.

Goldstein, K.M., Cary, Gene, Chorost, Sherwood, Dalach, John 1970. "Fanily Patterns and the School Performance of Emotionally Distrubed Boys", Journal of Learning Disabilities, V. 3 (1), Jan., 10-15.

Goodenough, Florence L. 1949. Mental Testing, Rhinehart \& Co., Inc., New York.

Graham, Philip, Rutter, Mjchael, George, Sandra 1973. "Temperamental Characteristics as Predictors of Behavion Disorders in Children", American Journal of Orthopsychiatry, V. 43 (3), Apr., 328-39.

Grossman, Herbert 1965. Teaching the Emotionally Disturbed: A Casebook, Holt, Rinehart. E Winston, Inc., New York.

Hartup, William i965. "Social Behavior of Children", Review of Educational Research, V. 35 (2), April, 122-29.

Hewett, Frank M. 1968. The Emotionally Disturbed Child in the Classroom, Allyn \& Bacon, Inc., Boston.

Hillman, Bill 1972. "The Family Constellation: A Clue to the Behavjor of Elementary School Children", Elementary School Guidance and Counseling, V. 7 (1), Oct., 20-25. 
Hunter, Carol P., Meyers, C.E. 1972. "Classroom Climate and Fupil. Characteristics in Special Classes for the Educationally Handicapped", Journal of School Psychology, V. 10 (1), Mar., 25-32.

Hotchkiss, 1967. "The Modification of Maladaptive Behavior of a Class of Educationally Handicapped Children by Operant Conditioning", Dissertation Abstracts, V. 27 (12-A), 4129-4130.

Isaac, Stephen 1971. Handbook in Research and Evaluation For Education and the Behavioral Sciences, Robert R. Knapp, San Diego, Cal.

Johnson, Orville, Black, Harriet 1968. Exceptional Children Research Review, Council for Exceptional Children, Wash. D.C.

Keogh, Barbara, Becker, Laurence 1973. "Early Detection of Learning Problems: Questions, Cautions and Guidelines", Exceptional Children, V. 40 (1), Sept., 5-11.

Kiesler, Donald J. 1971. "Experimental Designs in Psychotherapy Research", Handbook of Fsychotherapy and Behavior Change, Ed. Bergin, Allen, Garfield, Sol L., John Wiley E Sons, New York.

Knoblock, Peter 1973. "Open Education for the Emotionally Distrubed", Exceptional Children, Y. 39 (5), Feb., 358-67.

Kohn, Martin, Rosman, Bernice L. 1973. "A Two Factor Model of Emotional Disturbance in the Young Child: Validity and screening Efficiency", Journal of Child Psychology and Psychiatry and Allied Disciplines, V. I4 (I), Mar., 31-56.

Kounin, Jacob S. 1968. Managing Emotionally Disturbed Children in the Regular Classroom", Journal of Special Education, V. 2 (2), Winter, I29-35.

La Rouse, Rena, Monk, Mary 1964. "Behavior Deviations in a Representative Sample of Children", American Jounnal of: Orthopsychiatry, V. 34 (3), Apr., 436-47.

Lisle, James 1968. "Comparative Effectiveness of Various Group Procedures Used with Elementary Pupils with Personal-Social Adjustment Problems", Dissertation Abstracts, V. 28, June, 4485-A.

Lynch, Ruth M. 1972. "An Instruction School--A Practicum", Psychotherapy and Psychosomatics, V. 20 (3-4), 148-156.

MacMillan, Donald L. 1970. "Behavion Modification: Limitations and Liabilities", Exceptional Children, V. 37 (4), 291-97. 
Maes, Wayne 1966. "The Identification of Emotionally Disturbed Elementary School Children", Exceptional Children, V. 32 (9), May, 607-12.

Mann, Lester 1971. "Psychometric Phrenology and the New Faculty Psychology: The Case Against Ability Assessment and Training", Jounnal of Special Education, $V$. 5 (1), 3-2l.

Martin, Roy 1972. "Student Sex and Behavior as Determinants of the Type and Frequency of Teacher-Student Contacts", Journal of School Psychology, V. 10 (4), Dec., 339-47.

McKinnon, Archie I. 1970. "Parent and Pupil Perceptions of Special Classroom for Emotionally Disturbed Children", Exceptional Children, V. 37 (4), Dec., 302-03.

MenoCaseino, Frank 1965. "Emotional Disturbance and Mental Retardation", American Journal of Mental Deficiency, V. 70, Sépt., $248-57$.

Miller, Charles 1969. "Dual Authority Problerns in Classes for the Emotionally Disturbed", Psychology in the Schools, V. 6 (4), 404-09.

Miller, Lovick 1972. "School. Behavior Check. List: An Inventory of Deviant Behavior for Elementary School Children", Journal of Consulting and Clinical Psychology, V. 38 (1), Feb., 134-44.

Maurone, R. Thomas, Anderson, Nancy 1970. "School Program for Disturbed Children", American Journal of Orthopsychiatry, V. 40 (4), July, 694-701.

Montanari, A.J. 2973. "Helping Troubled Children in a Strained Economy", Exceptional Children, V. 39 (7), Apr., 559-63.

Moore, T. 1966. "Difficulties of the Ordinary Child Adjusting to Primary School", Journal of Child Psychology and Psychiatry, V. $7(.1), 17-38$.

Morse, William C., Butler, Richard L., Fink, Albert H. 1964. Public School Classes for the Emotionally Handicapped: A Research Analysis, The Council for Exceptional Children, NEA.

Novack, Harry S., Bonaventura, Elisa, Merenda, Peter P. 1973. "A Scale for Early Detection of Children with Learning Problems", Exceptional Children, V. 40 (2), Oct., 98-105.

Nowicki, Stephen, Walker, Charlotte 1973. "Achievement in Relation to Locus of Control: Identification of a New Sounce of Variance", Jounnal of Gerietic Psychology, V. 123 (1), Sept., 6367. 
Oakland, Thomas 1969. "Diagnostic Help 54: Examiner is in", Psychology in the Schools, V. 6 (4), 359-67.

Patrick, Sister M. 1965. "Identifying the Fmotionally Disturbed", Catholic School Journal, V. 65 (8), Oct., 47-8.

Quay, Herbert C. 1963. "Some Basic Considerations in the Education of Emotionally Disturbed Children", Exceptional Children, V. 30 , Sept., 27-30.

1966. "Pensonality Patterns of Pupils in Special Classes for the Emotionally Disturbed", Exceptional Children, V. 32 (5), Jan., 297-301.

1968. "The Facets of Educational Exceptionality: A Conceptual Framework for Assessment, Grouping and Instruction", Exceptional Children, V. 35 (1), 25-32.

Radin, Eric 1968. "Orthopsychiatry and Special Services for Emotionally Disturbed Children in a Public School Setting", Journal. of School Health, V. 48, Sept., 245.

Redl, Fritz, Wattenberg, William 1959. Mental Hygiene in Teaching, Harcourt Brace \& Co., New York.

Register, Mary, L'Auate, Luciano 1972. "The Clinical Usefulness of an Objective Nonverbal Personality Test for Children", Psychology in the Schools, V. 9 (4), Oct., 378.

Rickard, Henry, Nelvin, Kenneth, Creel, Joe, Creel, Laura "The Effects of Bonus Tokens Upon Productivity in a Remedial Classroom for Behaviorally Disturbed Children", Behavior Therapy, V. 4 (3), May, 378-85.

Rider, Barbara 1973. "Perceptual-Motor Dysfunction in Emotionally Disturbed Children", American Journal of Occupational Therapy, V. 27 (6), Sept., 316-20.

Ruedi., Jane, West, Charles 1973. "Pupil. Self-Concept in an 'Open' School and in a 'Traditional' School", Psychology in the Schools, V. 10 (1), Jan., 48-53.

Sadker, David, Sadker, Myra, Cooper, James M. 1973. "Elementary School. Through Children's Eyes", Elementary School Journal, V. 73 (6), Mar., 289-96.

Saunders, Bruce, Tullio, William 1972. "lhe Fajlure of Biased Informa-tion to Affect Teacher Behavior Ratings and Peer Sociometric Status of Disturbing Children in the Classroom", Psychology in the Schools, V. 9(4), Oct., 440-45. 
Saunders, Bruce 1972. "A Procedure for the Screening, Identification and Diagnosis of Emotionally Disturbed Children in the Rural Elementary School", Psychology in the Schools, V. 9 (2), Apr., 159-64.

Scaefer, Charles 1973. "An Explonatory Study of Teachers' Descriptions of the 'Ideal' Pupil", Psychology in the Schools, V. 10 (4), Oct., 444-47.

Scagliotta, Edward 1971. "And the Pendulum Swings", Journal of Special Education, V. 5 (1), 41-44.

Schaefer, Charles, Millman, Howard L. 1973. "The Use of Behavior Ratings in Assessing the Effect of Residential Treatment with Latency Age Boys"; Child Psychiatry and Human Development, V. 3 (3), Spring, 157-64.

Schulz, Edward, Hirshoren, Alfred, Manton, Anne, Henderson, Robert 1971. "Special Education for the Emotionally Disturbed", Exceptional Children, V. 38 (4), Dec., 313-19.

Shotel, Jay, Iano,' Richard, McGettigan, James 1972. "Teacher Attitudes Associated with the Integration of Handicapped Children", Exceptional Children, V. 38, May, 677-86.

Shores, Richard E., Haubrich, Paul 1969. "Effect of Cubicles in - Educating Emotionally Disturbed Children", Exceptional Children, V. 36 (1), Sept., 21-24.

Simeonsson, Rune J. 1573. "Egocentric Responses of Normal and Emotionally Disturbed Children in Different Treatment Settings", Child Psychiatry and Human Development, V. 3 (3), Spring, 17986 .

Snapp, Mathew, McNeil, Don, Harig, Diane 1973. "Deyelopment of InSchool Psychoeducational Services for Emotionally Disturbed Children", Psychology in the Schools, V. 10 (4), Oct., 392-6.

Spivach, G., Swift, M., Prewitt, J. 1971. "Syndromes of Disturbed Classroom Behavion: A Behavional Diagnostic System for Elementary Schools", Journal of Special Education, V. 5 (3), 269-92.

Stennett, R.G. 1966. "Emotional Handicap in the Elementary Years", American Journal of Orthopsychiatry, V. 36 (3), 444-49.

Stone, Beth, Rowley, Vinton 1964. "Educational Disability in Emotionally Disturbed Children", Exceptional Children, V. 30 (9), May, 423-26.

1969. "Effects of Social Approval on the Verbal Behavioral of Emotionally Disturbed and Normal Children", Jounnal of Abnormal 
Psychology, V: $73(6), 321-25$.

Swanson, Bernice M., Parker, Harry U. 1971. "Parent-Child Relations: A Child's Acceptance by Others, of Dthers, and of Self", Child Psychiatry and Iluman Development, V. 1. (4), Summer, 243-54.

Swift, Marshal, Feldman, David, Bratton, Joseph 1972. "Children's Disturbing Classroom Behavior, A Cross Cultural Investigation", Exceptional Children, V. 38 (6), Feb., 492-3.

Tolvin, Alexander 1968. "An Experimental Approach to the Treatment of Disturbed School-Aged Children", School Counselor, V. 16 (2), Nov., 97-101.

Vacc, Nicholas 1972. "Long-Term Effects of Special Class Intervention for Emotionally Disturbed Children", Exceptional Children, V. 39 (1), Sept., 15-22.

1972. "Spontaneous improvement in the Social Positions of Emotionally Disturbed Children in Regular Classes", Psychological Reports, V. 31 (2), Oct., 634-45.

Vander Kold, Charles 1973. "Para-Professionals as 'Psychotherapeutic Agents' with Moderately Disturbed Children", Psychology in the Schools, V. I0,Apr., 238-42.

Wagonseller, Bill R. 1973. "Learning Disability and Emotional Disturbance: Factors Relating to Differential Diagnosis", Exceptional Children, V. 40, Nov., 205-6.

Walker, Harriet 1945. A History of Special Education, Portland Public Schools, Department of Child Study and Special Education, June.

Walker, Hill M., Buckley, Nancy K. 1972. "Effects of Reinforcement, Punishment, and Feedback Upon Academic Response Rate", Psychology in the Schools, V. 9 (2), Apr., 186-93.

Wallen, Thomas 1970. "Evaluation of a Program of Special Classes For 'Disruptive Children' in an Urban School System", Community Mental Health Journal, V.. 6 (4), August, 276-84.

Wanner, Frank, Thrapp, Robert, Walsh, Suzanne, 1973. "Attitudes of Childnen Toward Thein Special Class Placement", Exceptional Children, V. 40 (I), 37-8.

Weissman, Herbert N. 1970. "Implications for the Education of Children with Emotional and Social Disturbances", Jounnal of Learning Disabilities, V. 3(10), Oct., 20-26. 
Westman, Jack C. 1967. "Nursery School Behavion and Later School Adjustment", American Jounnal of Orthopsychiatry, V. 37, July, $725-31$.

Weinstein, Iaura 1969. "Re-education Schools for Emotionally Disturbed Children: Effectiveness as Viewed by Referring Agencies, Parents, Teachers", Exceptional Children, V. 35 (9), May, 70311.

Wetter, Jack, French, Ronald W. 1973. "Comparison of the Peabody Individual Achievement Test and the Wide Range Achievement Test in a Learning Disability Clinic", Psychology in the Schools, V. 10 (3), 285-6.

Whelan, Richard 1966. "Modification and Maintenance of Behavior through Systematic Application of Consequences", Exceptional Children, V. 32 (5), Jan., 281-89.

Wiltz, N.A. 1973. "Behavional Therapy Techniques in Treatment of Emotionaliy Disturbed Children and their Families", Child Weifare, V. 52, Oct., 483-92.

Winkler, Ronald C. 1965. "Effects of Selected Counseling and Remedial Techniques on Underachieving Elementary Children", Journal of Counseling Psvchology, V. 12 (4), 384-87.

Wood, Frank, Johnson, Ardes 1972. "Coopersmith Self-Esteem Inventory Scores of Boys with Severe Behavion Problems", Exceptional Children, V. 38 (9), May, 739-40.

Zive, Avner 1970. "Children's Behavior Problems as Viewed by Teachers, Psychologists and Children", Child Development, V. 41 (3), 87l79 . 
XIđNGd 


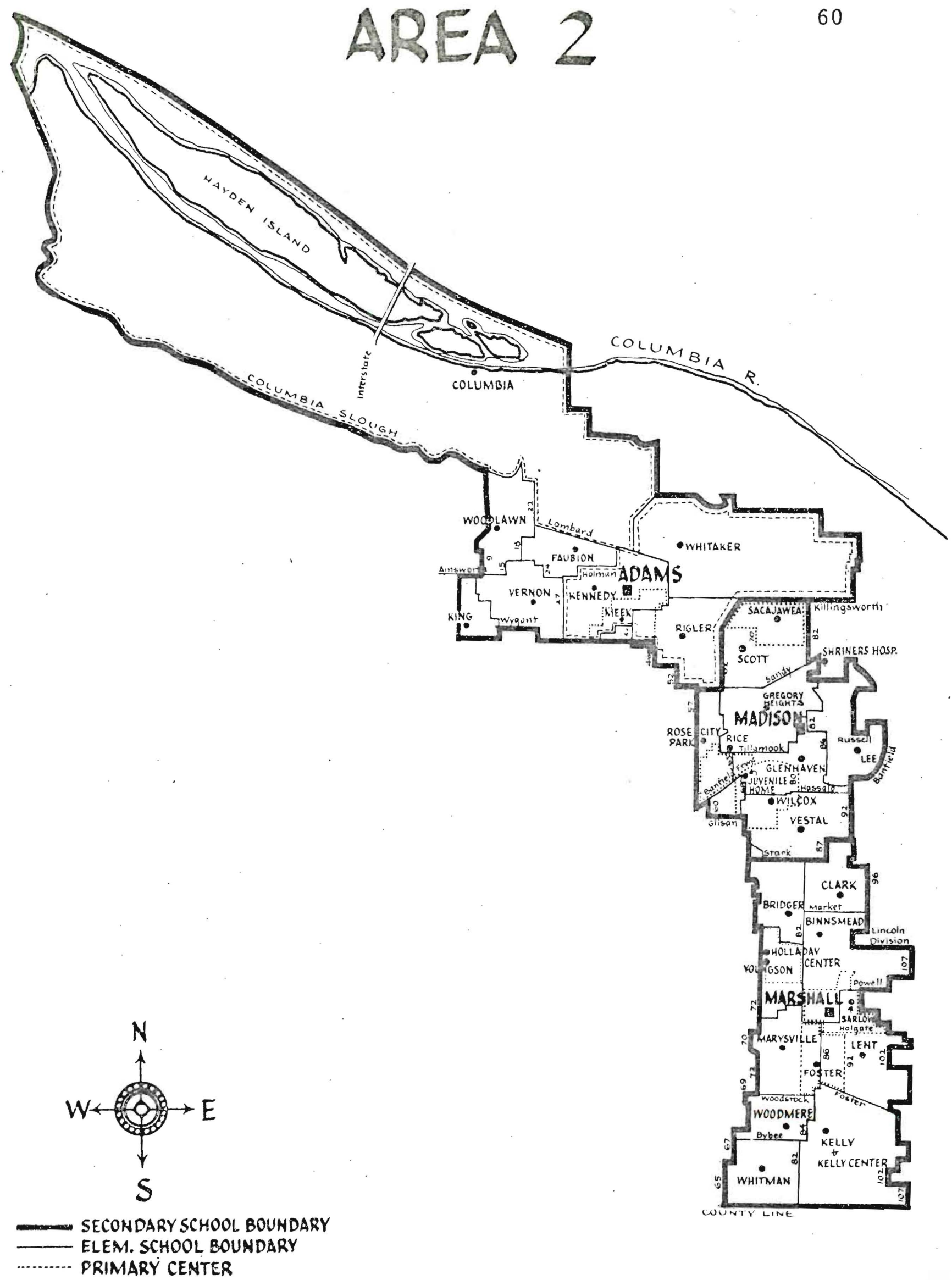




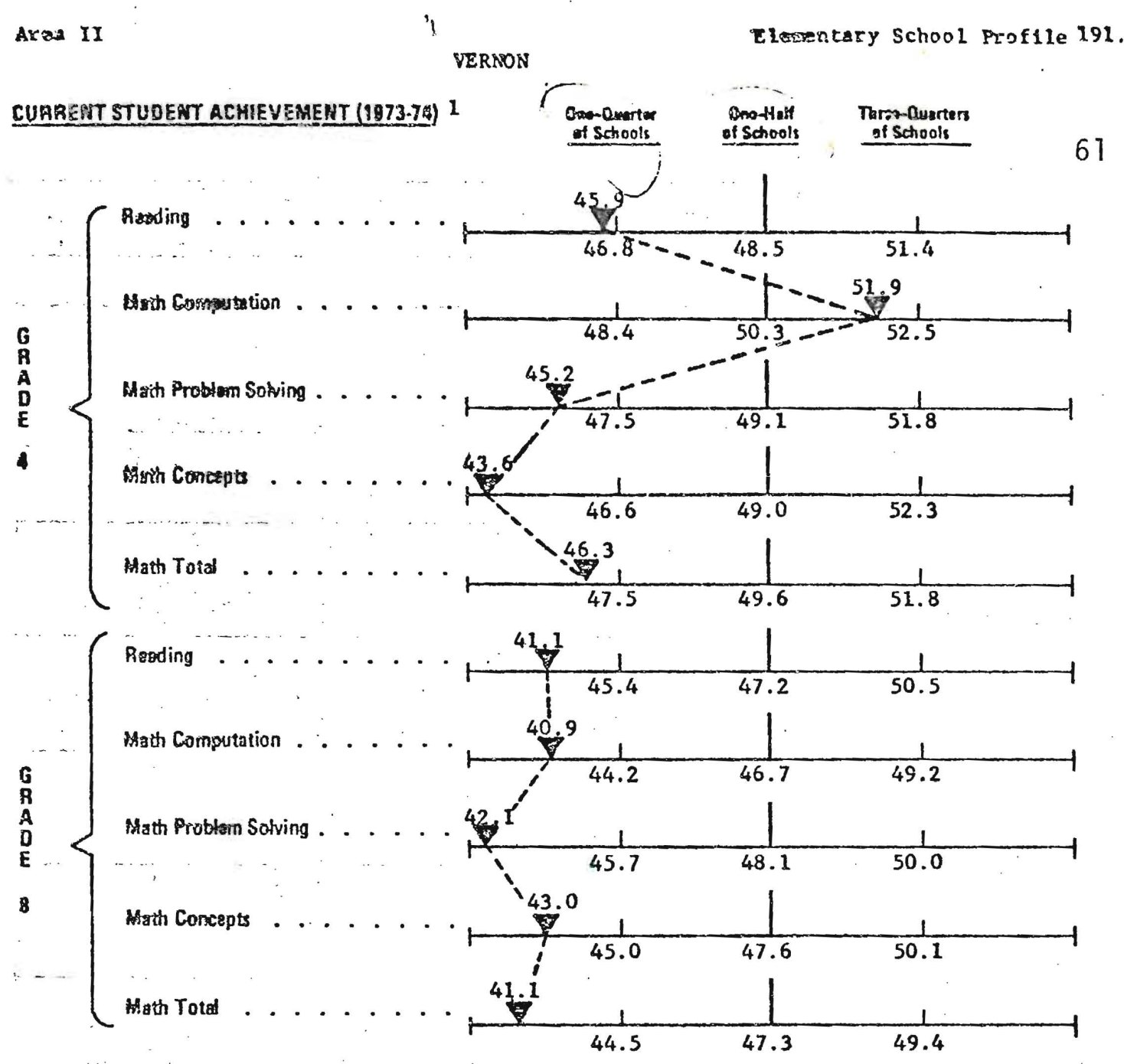

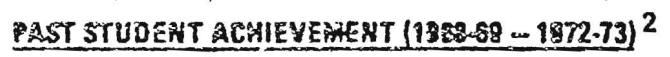
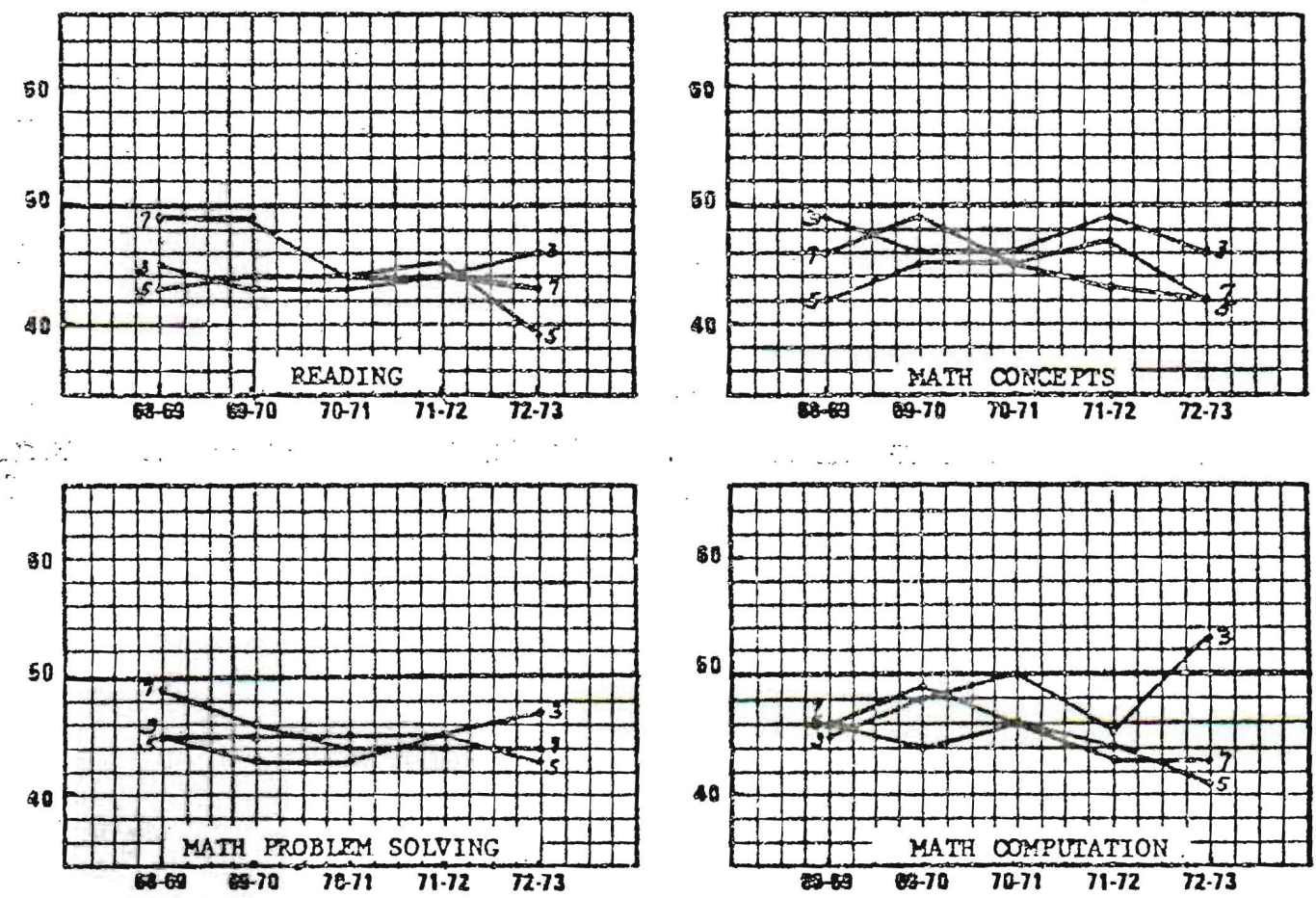

\section{NOTES ON ACHIEVESEET DATA:}

1. Fall'73, Hetropolitan Area Ave. M-score 50.

2. 5-yr. period '68-69 thru '72-73, Local (Norm-base yr. '69-70) P-score Ave. 50. 72-73 cores y be sightly higher than in previous years due to later testing date. 
VERNON

SCHOOL DATA (1973-74)

\begin{tabular}{|c|c|c|c|c|c|c|c|c|c|}
\hline \multirow[b]{2}{*}{ Gradu } & \multirow[b]{2}{*}{ Exrostement } & \multirow{2}{*}{\multicolumn{2}{|c|}{$\begin{array}{l}\text { Admiviedersine } \\
\text { Tranders }\end{array}$}} & \multicolumn{3}{|c|}{ stat * } & \multirow{2}{*}{ 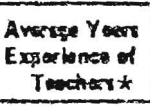 } & \multirow{2}{*}{ 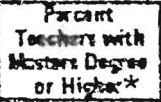 } & \multirow{2}{*}{$\begin{array}{c}\text { Purcont } \\
\text { Teochers Not on } \\
\text { Tonwes * }\end{array}$} \\
\hline & & & & $\begin{array}{l}\text { Cenvitiented } \\
\text { Teothers }\end{array}$ & Aidon & & & & \\
\hline$x-8$ & 622 & 0 & 0.0 & 24.50 & 13.00 & 2.00 & 7.38 & 6.12 & 40.82 \\
\hline
\end{tabular}

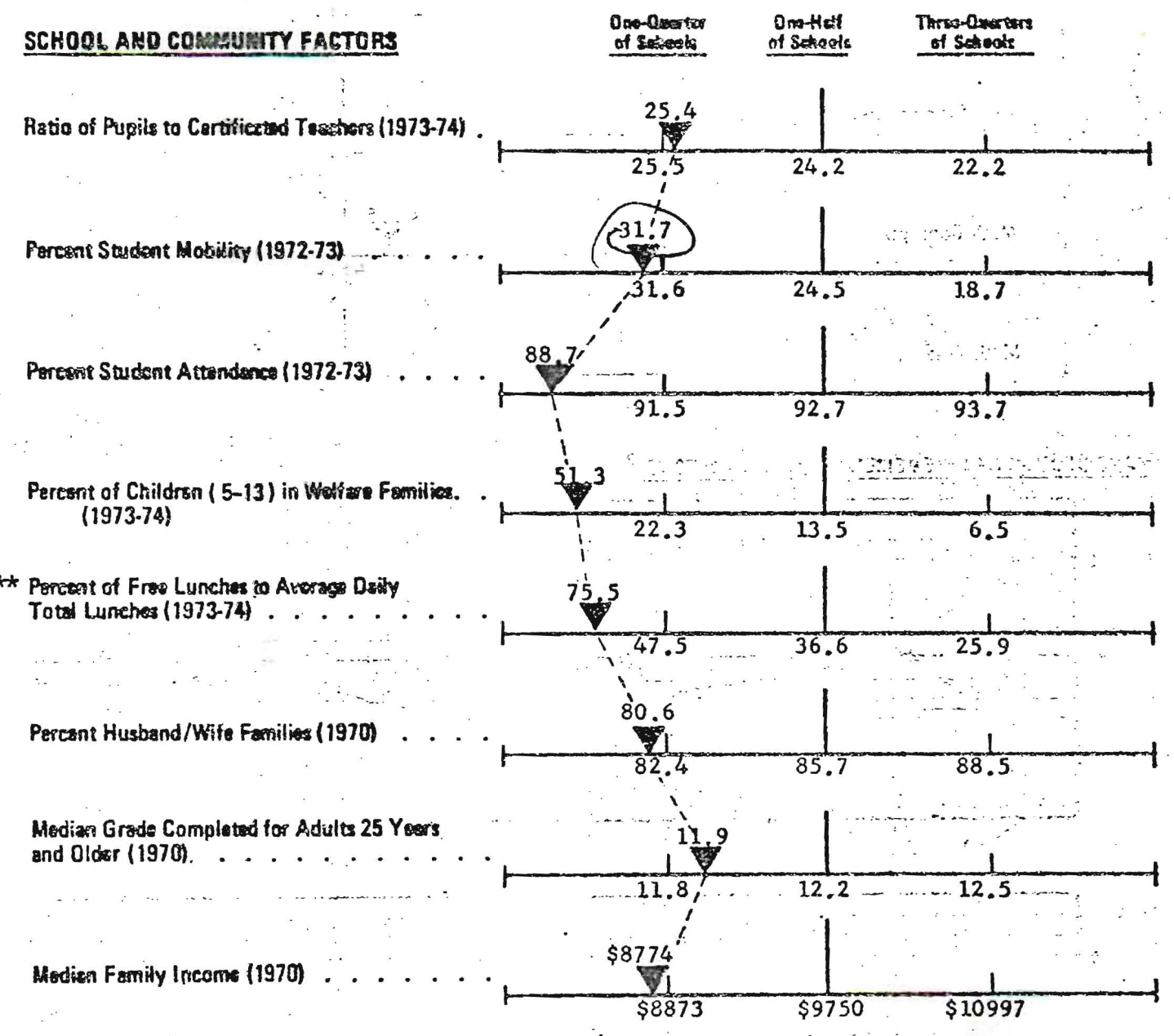

ETHEAC COMPCSTIOT OF STUDEMTS AND STAFF-1973-74

\begin{tabular}{|c|c|c|c|c|c|c|c|c|c|c|c|c|}
\hline & \multicolumn{2}{|c|}{ White } & \multicolumn{2}{|l|}{ Bare } & \multicolumn{2}{|c|}{ Arien Amcricas } & \multicolumn{2}{|c|}{ Surnecred Amorices } & \multicolumn{2}{|c|}{ Ambries InElisa } & \multicolumn{2}{|c|}{ Not Speritied } \\
\hline & Number & $\%$ & Numbsr & $\%$ & Number & $\%$ & Numbor & \% & Numbsr & $\%$ & Numbar & $\%$ \\
\hline & 279 & 42.2 & 357 & 53.9 & 8 & 1.2 & 6 & 0.9 & 12 & 1.0 & $\underline{0}$ & 10,0 \\
\hline m & 26.00 & 65.8 & 12.00 & 30.4 & 0.00 & 0.0 & 0.00 & 0.0 & 0.00 & 0.0 & 1.50 & 3.8 \\
\hline
\end{tabular}

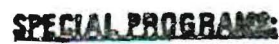

Career Education ard Work Expertence, Cooperactve Tutoring Programs with Instltutions of Higher Lesraing, Cooperstive Tutorling Progrsms of th Lacsl Rlementary or gigh Schools, DISTAR Resding, Edscetional Developientid lisoretory (EDL), Extended Day Progrem, 4-H Progran,McGrmo-Hill-Sullivan Resding Improvement Program, officer Friendly Progran, Perceptual Mator Activities Program, Preschool Progras for Preschooler with Specil 1 Needs, Reading Skill Development Center, TREND, Young Audienced, Inc., State Dlsadventaged Progigira, ESEA TItla I

* Statistics based upon actual teaching tim of personnel in terres of Y.T.E. (Ful1 Time Equivalent).

* Lunches refer to Class A (hot plate) lunches only. 


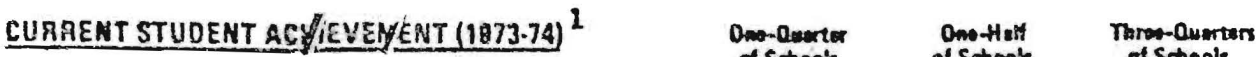

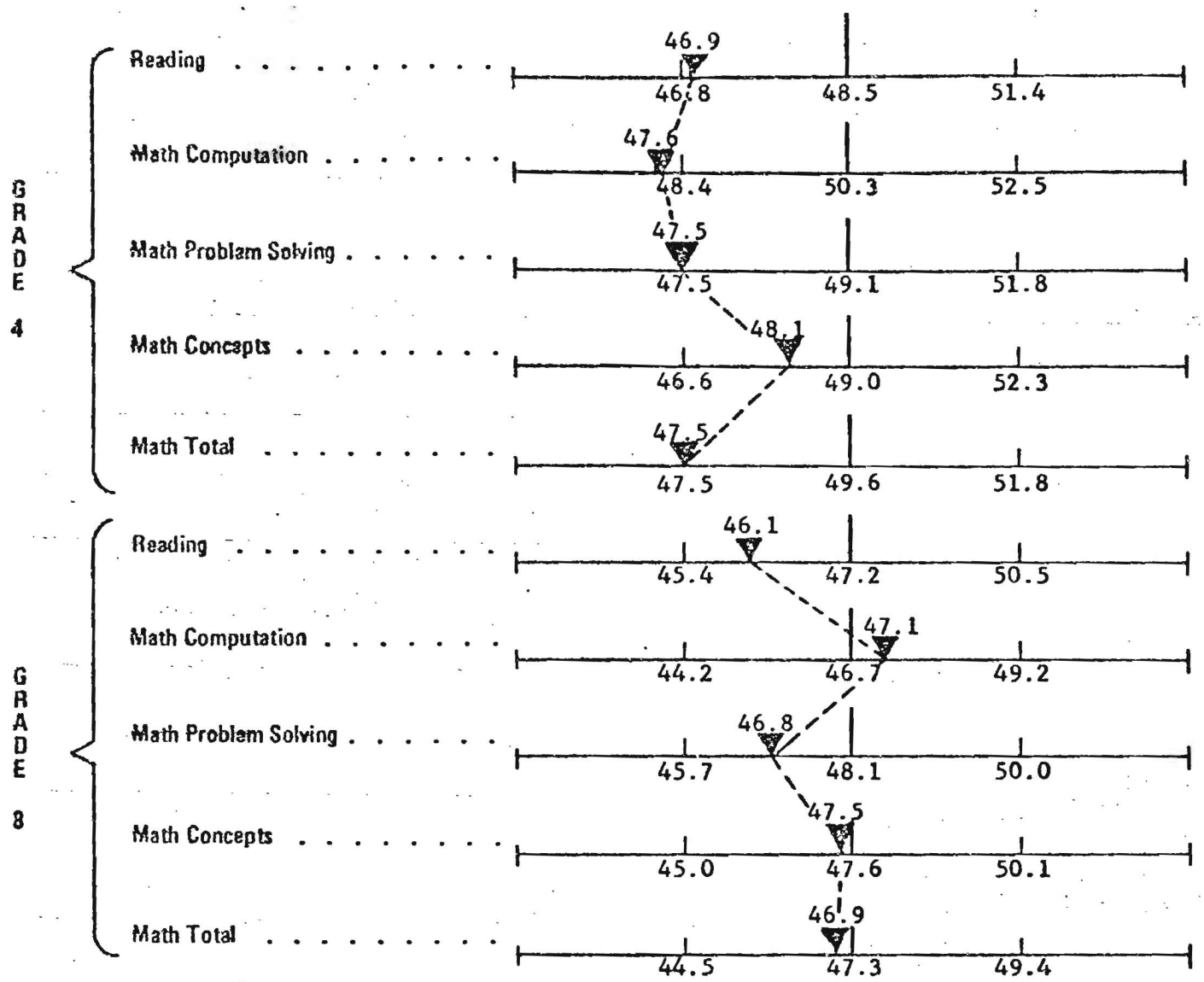

PAST STUDERT ACHIEVERENT (1938 $09-9872-73)^{2}$
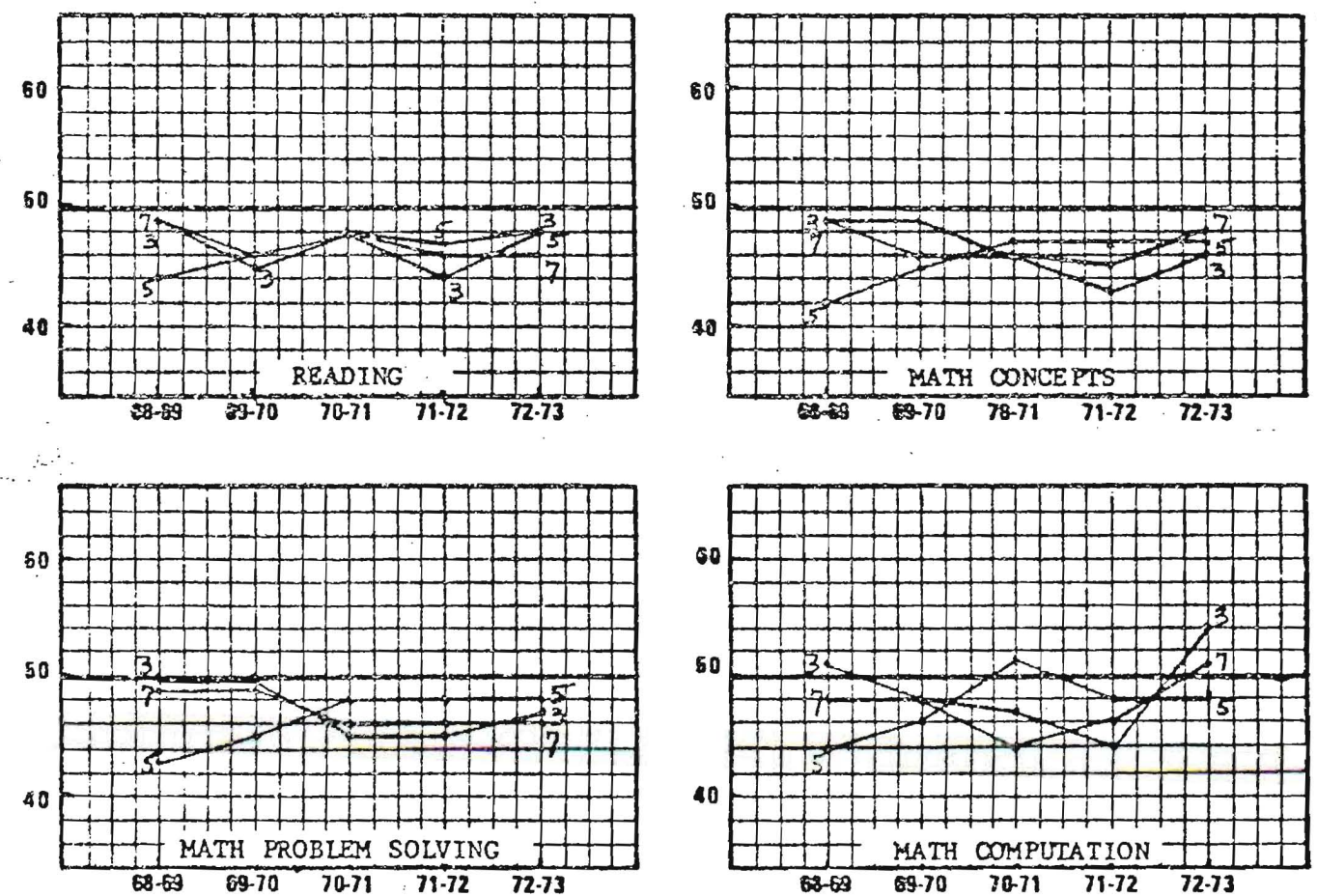

\section{NOTES ON ACHIEVEMENT DATA:}

1. Eall'73, letropolitan Area Ave. M-score 50.

2. 5-yr. period '68-69 tinru 72-73, Locsl (Norm-base yr. 169-70) P-score Ave. S0.

'72-73 вcores my be slight1; bigher than in previous years due to later testing date. 
LENT

SCHOOL DATA (1973.74)

\begin{tabular}{|c|c|c|c|c|c|c|c|c|c|}
\hline \multirow[b]{2}{*}{ Grader } & \multirow[b]{2}{*}{ Entatimax } & \multicolumn{2}{|c|}{$\begin{array}{l}\text { Adminternives } \\
\text { Tromeders }\end{array}$} & \multicolumn{3}{|c|}{ sutf * } & \multirow{2}{*}{ 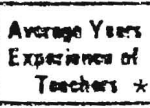 } & \multirow{2}{*}{ 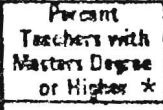 } & \multirow{2}{*}{$\begin{array}{c}\text { Porcant } \\
\text { Treecters Net or } \\
\text { Tenure } \\
\end{array}$} \\
\hline & & Hestion & & $\begin{array}{l}\text { Crrtifieation } \\
\text { Tecolione }\end{array}$ & Anders & Albrinietreter & & & \\
\hline$K-8$ & 638 & 9 & 1.4 & 27.60 & 2.00 & 1.00 & 15.02 & 22.46 & 12.32 \\
\hline
\end{tabular}

\begin{tabular}{|c|c|}
\hline SCHOOL ANO COMUNITY FACTORS & $\begin{array}{l}\text { Ono-Awerts } \\
\text { of Seloets }\end{array}$ \\
\hline
\end{tabular}
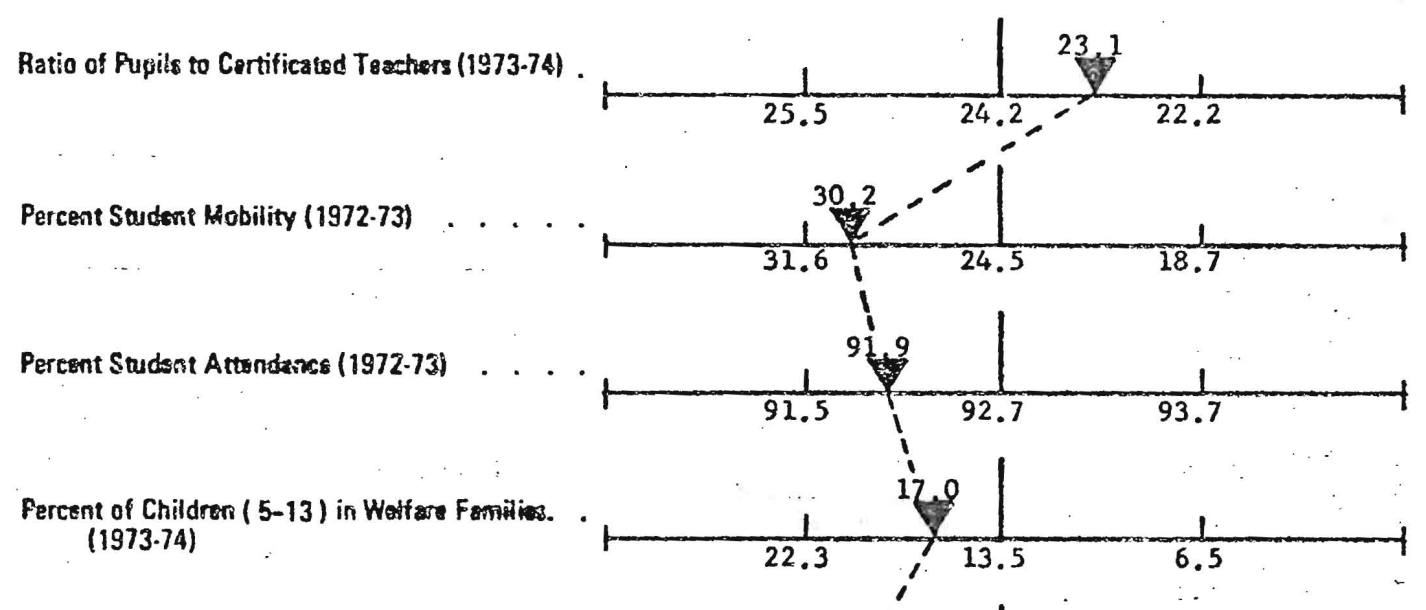

** Percent of Fro Lunches to Averege Dsily

Total Lunches (1973.74). A
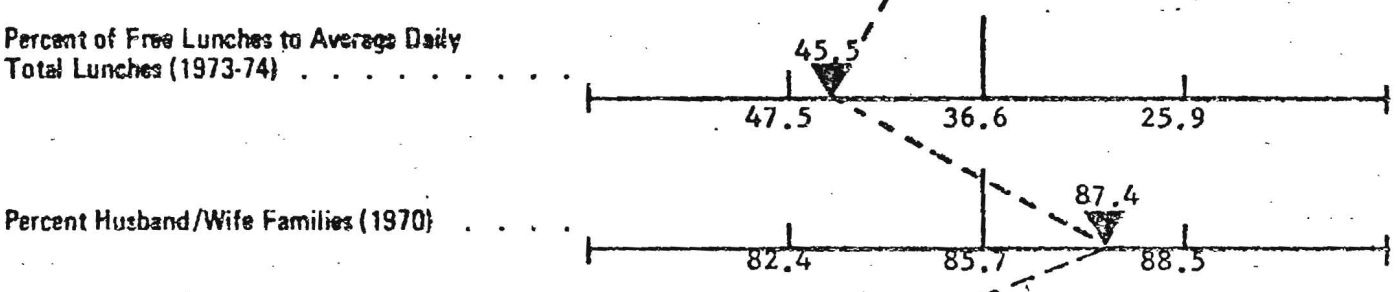

Hedian Grade Complated for Rdults 25 Yasers

and Older $(1970)$............

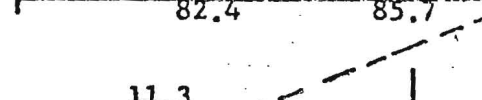

T

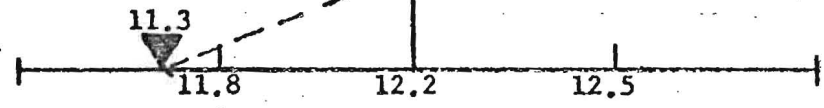

- Median Family Income (1970)

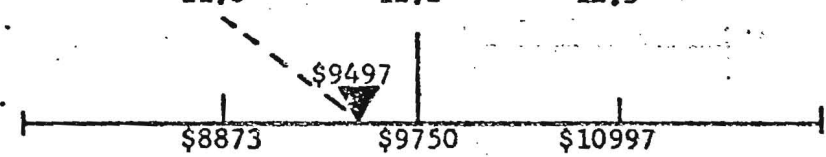

ETHRIC COMASOSTION OF STUOEMTS AMO STAFE - 1873-74

\begin{tabular}{l} 
White \\
\begin{tabular}{|c|c|c|c|c|c|c|c|c|c|c|c|}
\hline Number & $\%$ & Number & $\%$ & Number & $\%$ & Number & $\%$ & Number & $\%$ & Number & $\%$ \\
\hline
\end{tabular} \\
\hline
\end{tabular}

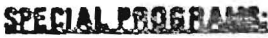

Appleton-Century-Croft Verbal Skills Reading Laboratory, Career Education, CATCH Progran, Itinerant Language Learning Disorders, Preechol Program for Preschooler with Special Needs, Project Career Education (PCE 7-10), ESEA Title VII

* Statistics based upon actusl teaching time of personnel, in terms of F.T.E. (Full Time Equivalent).

*t Lunches refer to class A (hot plate) lunches only. 
CURAENT STUOENT ACHIFVEMENT (1973-74) ${ }^{1}$

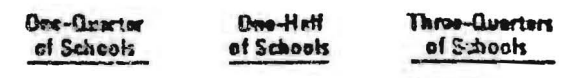

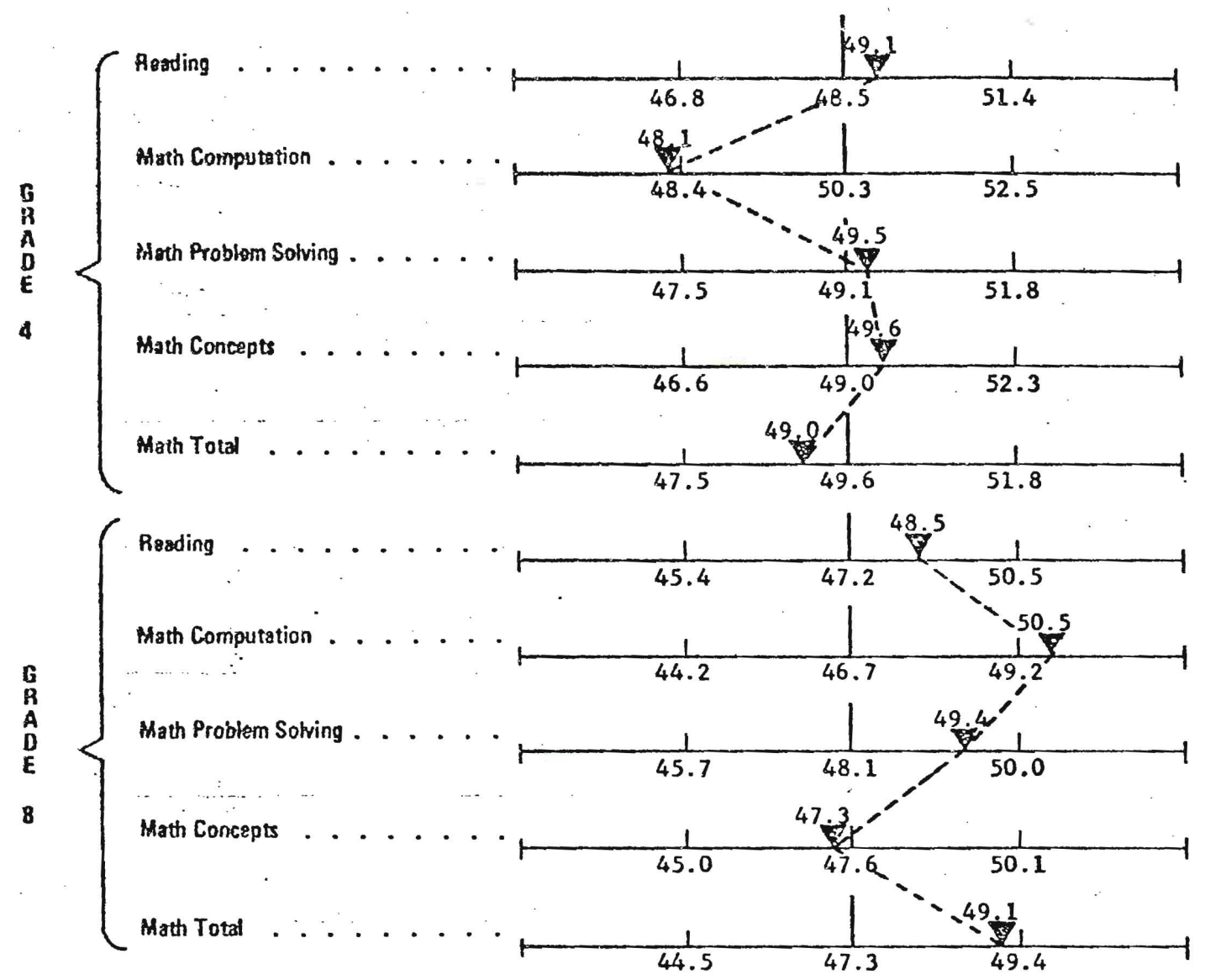

PAST STUDENT ACHIEVEMERT (1008\%9-9972.73) ${ }^{2}$
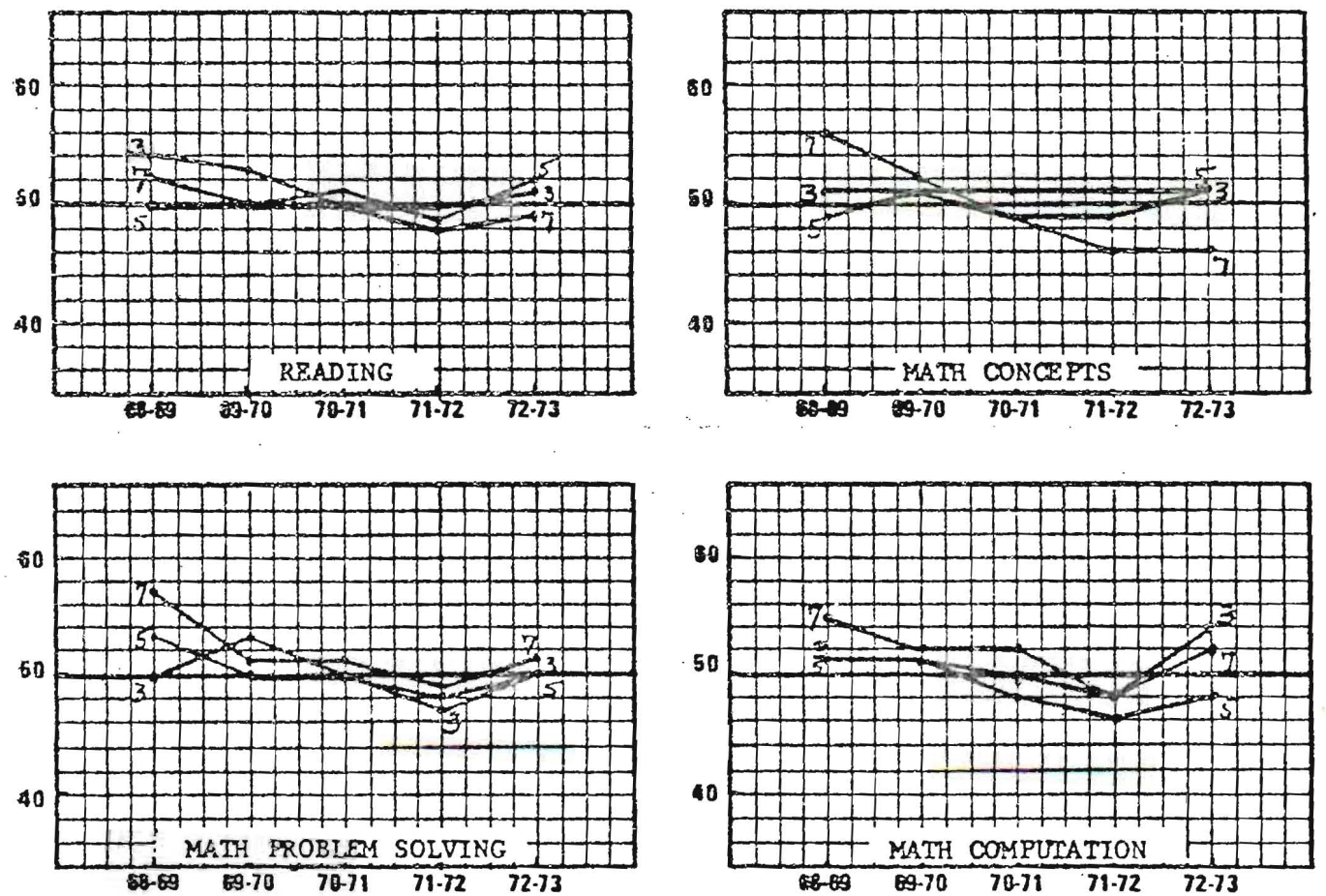

\section{NOTES ON ACHIEVEGENT DATA:}

1. Fall'73, Metropolitan Area Ave. M-Bcore 50.

2. 5-yr. period '68-69 thru '72-73, Local (Norm-base yr. '69-70) P-score Ave. 50.

' $72-73$ Bcores y be slightly higher than in previous years due to later testing date. 
Scotr

SCHOOL DATA (1973.74)

\begin{tabular}{|c|c|c|c|c|c|c|c|c|c|}
\hline \multirow[b]{2}{*}{ Grader } & \multirow[b]{2}{*}{ Eoroliman } & \multicolumn{2}{|c|}{$\begin{array}{l}\text { Adminatertive } \\
\text { Tronsturs }\end{array}$} & \multicolumn{3}{|c|}{$\operatorname{sint} *$} & \multirow{2}{*}{$\begin{array}{l}\text { Anerm Years } \\
\text { Experix oce of } \\
\text { Yeschess }\end{array}$} & \multirow{2}{*}{ 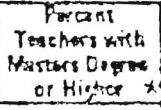 } & \multirow{2}{*}{$\begin{array}{c}\text { Percant } \\
\text { Teectus Not ox } \\
\text { Tenare } \star\end{array}$} \\
\hline & & Numbor & & 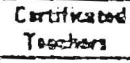 & Aidre & Administriton & & & \\
\hline$K-8$ & 615 & 33 & 5.4 & 27.00 & 1.00 & 1.00 & 18.67 & 37.04 & 12.96 \\
\hline
\end{tabular}

\begin{tabular}{|c|c|}
\hline SCHOCL AND COMEUHITY FACTORS & $\begin{array}{l}\text { Onx-Querth } \\
\text { of Solteek }\end{array}$ \\
\hline
\end{tabular}

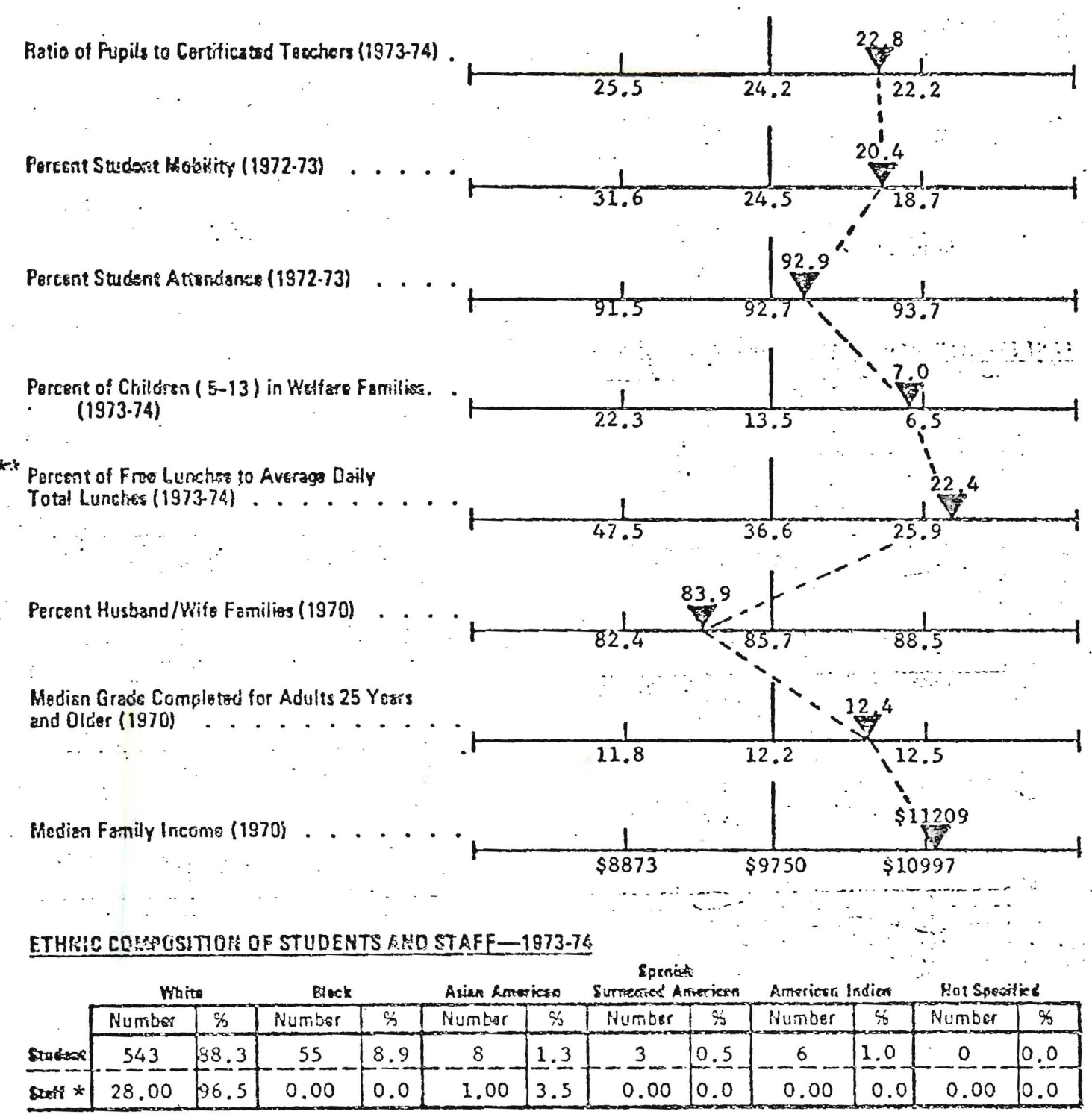

\section{SPECLLERSGAALE:}

Computer Mathemstics, DISTAR keading, 4-H Program, Speclal Education Programs for Mentally Retarded, VIPS, State DHsadvantaged Prograns, ESEA Title VII

* Statistics based upon actual teaching time of personnel in terms of F.T.E. (Full Tize Equivalent).

* Lunches refer to Class A (hot plate) lunches only. 


\section{Guidelines for Behavior Categories}

1. An inability to learn which cannot be adequately explained by intellectual, sensory, neurophysiological, or general health factors.

An inability to learn is, perhaps, the single most significant characteristic of emotionally handicapped children in school. Nonlearning of this kind may be manifested as an inability to profit from any school learning experiences as well as an inability to master skill subjects. The non-learner may fall behind almost imperceptibly in the first few grades but finds himself in deep water by the time he reaches 4th grade. There are some students, too, who seem to be keeping pace until they reach junior high school, when they begin to flounden badly.

By whatever symptoms the inability manifests itself, we will, as educators, seek the cause or causes." And once we have ruled out intellectual, sensory, neurological, and general health factors, there remain emotional conflicts and resistances to be investigated as major causes of learning disabilities.

2. An inability to build or maintain satisfactory interpersonal relationships with peers and teachers.

It is not just "getting along" with others that is significant here. The term "satisfactory interpersonal relations" refers to the ability to demonstrate sympathy and warmth toward others, the ability to stand alone when necessary, the ability to have close friends, the ability to be aggressively constructive, and the ability to enjoy working and playing with others as well as to enjoy working and playing by oneself. In most instances, children who are unable to build or maintain satisfactory interpersonal relationships are noticed by their peers, or are most clearly visible to their peers. Teachers, however, are also able to identify many such children after a period of observation.

3. Inappropriate or immature types of behavior or feelings under normal conditions.

Inappropriateness of behavior or feeling can often be sensed by the teacher and peer groups. "He acts like a baby almost all the time," or "he acts funny lots of times," are judgments often heard that describe such behavior. The teacher may find some children reacting to a simple command, like "Please take your seat," in wildly disparate or incongruous ways. What is appropriate or inappropriate, mature or immature, is best judged by the teacher using "his professional training, his daily and long-term observation of the child, and his experience working and interacting with the behavior of large numbers of children. 
4. A general pervasive mood of unhappiness or depressions.

Children who are unhappy most of the time may demonstrate such feelings in expressive play, art work, written composition, or in discussion periods. They seldom smile and usually lack a "joy of living" in their school work or social relationships. In the middle or upper grades a self-inventory is usually helpful in confirming suspicions about such feelings.

5. A tendency to develop physical symptoms, such as speech problems, pains, or fear, associated with personal on school problems.

often, this tendency is first noted by the child himself. Illness may be linked regularly to school pressures or develop when a child's confidence in himself is under stress. Speech difficulties resulting from emotional distress are usually painfully audible to the teacher and parent.

To sum up, then: the significant patterns of behavior in children indicating a need for closer scrutiny by a teacher are: inability to learn', unsatisfactory interpersonal relationships, inappropriate behavior, unhappiness, repetitive symptoms of illness after stress. . . 
TEACHER ASSESSMENT OF CHILD BEHAVIOR IN REGULAR CLASSROOM

Based on Frank M. Hewett's attention, response, order, exploratory, social and mastery inventories presented in The Emotionally Disturbed Child in the Classroom, Allyn \& Bacon, Inc., Boston, 1968.

Please check the appropriate boxes describing the classroom behavion of the following child

ATTENTION

i. Child does not pay attention to learning tasks. Child never pays attention to learning tasks. Child often do'es not pay attention to learning tasks. Child occasionally does not pay attention to learning tasks.

2. Child prefers fantasy to reality. Child out of contact with reality. Child often daydreams. Child occasionally daydreams.

3. Child's beliefs and interests are inappropriate. Child has extremely bizarre beliefs and interests. Child has distorted beliefs about his environment. Child's beliefs and interests immature for sex and age.

4. Child does not pay attention to teacher. Child never pays attention to teacher. Child often does not pay attention to teacher. Child occasionally does not pay attention to teacher. 
5. Child does not profit from instruction.

Child never retains and uses instruction he has been given. Child often does not retain and use instruction he has been given. Child occasionally does not retain and use instruction he has been given.

RFSPONSE

6. Child does not respond to learning tasks.

Child will never undertake a learning task.

Child often will not undertake a learning task.

Child occasionally will not undertake a learning task.

7. Child maintains a constricted level of performance. Child always controlled and rigid with learning tasks. Child often controlled and rigid with learning tasks. Child occasionally controlled and rigid with learning tasks.

8. Child exhibits a narrow range of learning interests. Child will never try a new or different learning task. Child often will not try a new or different learning task. Child occasionally will not try a new or different learning task.

9. Child withdraws from teacher and peers.

Child always avoids contact with teacher and peers. Child often avoids contact with teacher and peers. Child occasionally avoids contact with teacher and peers. 
10. Child cannot function in a regular classroom.

Child does not respond to tasks in individual tutoring.

Child does not respond to tasks in a special class on program.

Child does not respond to tasks in a regular classroom except

for brief periods of time.

\section{ORDER}

11. Child does not follow directions.

Child never follows directions when doing learning tasks.

Child often does not follow directions when doing learning. tasks.

Child occasionally does not follow directions when doing learning tasks.

12. Child is uncontrolled in learning.

Child always approaches learning tasks in an impulsive, uncritical manner.

Child often approaches learning tasks in an impulsive, uncritical manner.

Child occasionally approaches learning tasks in an impulsive, uncritical manner.

13. Child is disruptive in group.

Child always is disruptive in group.

Child often is disruptive in group.

Child occasionally is disruptive in group. 
14. Child does not finish learning tasks.

Child never finishes learning tasks.

Child often does not finish learning tasks.

Child occasionally does not finish learning tasks.

\section{EXPLORATORY}

15. Child overly dependent on others for choice of interests and activities.

Child completely dependent on others for choice of interests and activities.

Child excessively dependent on others for choice of interests and activities.

Child usually dependent on others for choice of interests and activities.

16. Child cannot do learning tasks because of motor, physical, sensory, perceptual, or intellectual deficits.

Please underline appropriate deficit.

SOCIAL

17. Child does not gain approval from others.

Child never gains approval from others.

Child often does not gain approval from others.

Child occasionally does not gain approval from others.

18. Child overly dependent on attention or praise from others. Child will only work with constant supervision and attention from the teacher. 
Child will only irork for brief periods of time without attention and praise from others.

Child often seeks attention and praise from others while doing learning tasks.

MASTERY

19. Child's functioning level in self-care and intellectual skills below capacity.

\section{(self-care)}

Extreme discrepancy between child's capacity and functioning level in self-care.

Considerable discrepancy between child's capacity and functioning level in self-care.

Slight discrepancy between child's capacity and functioning level in self-care.

\section{(intellectual skill)}

Extreme discrepancy between child's capacity and functioning level in intellectual and academic skills.

Considerable discrepancy between child's capacity and functioning level in intellectual and academic skills.

Slight discrepancy between child's capacity and functioning level in intellectual and academic skills. 